\title{
Seawater heat pumps in China, a spatial analysis
}

\author{
Chang Su ${ }^{\mathrm{a}, *}$, Hatef Madani ${ }^{\mathrm{a}}$, Hua Liu ${ }^{\mathrm{b}}$, Ruzhu Wang ${ }^{\mathrm{c}}$, Björn Palm ${ }^{\mathrm{a}}$ \\ ${ }^{a}$ Department of Energy Technology, KTH Royal Institute of Technology, Brinellvägen 68, S-100 44 Stockholm, Sweden \\ ${ }^{\mathrm{b}}$ State Key Laboratory of Air-Conditioning Equipment and System Energy Conservation, Gree Electric Appliances, INC., 519070 Zhuhai, China \\ ${ }^{\mathrm{c}}$ Institute of Refrigeration and Cryogenics, Shanghai Jiao Tong University, 200240 Shanghai, China
}

\section{A R T I C L E I N F O}

\section{Keywords:}

Seawater heat pump

Spatial analysis

Systematic method

Space heating

Space cooling

China

\begin{abstract}
A B S T R A C T
Fossil fuel based building space heating and cooling contribute to more than $10 \%$ total final energy consumption in China. Consequent carbon dioxide and air pollutants emissions bring about atmospheric pressure and associated respiratory diseases. Seawater heat pumps as a candidate sustainable building space heating and cooling solution can alleviate such environmental pressure since China has a long coastline and many coastal cities have the possibility for seawater heat pump implementation. However, stakeholders are still suffering from insufficient understanding of seawater heat pumps feasibility in different coastal cities of China from technoeconomic, environmental and geographical perspectives. This paper proposes a systematic method to evaluate seawater heat pump potential in different locations of China considering various local spatial parameters in the source and sink side of the energy system. A key performance indicator system is introduced to quantitatively analyze the relative advantages and disadvantages of applying seawater heat pumps compared with status-quo systems. Quantitative evaluation results show that seawater heat pumps have a higher potential in north Chinese coastal cities from techno-economic point of view when compared with existing heating and cooling systems. Environmentally, seawater heat pumps have to reach a critical seasonal coefficient of performance value to guarantee its potential in carbon emissions saving. In south Chinese coastal cities, seawater heat pumps have to reach a more satisfactory system efficiency and a more competitive system cost in order to exploit its full advantages over status-quo systems from techno-economic perspectives. Environmentally, seawater heat pumps are more attractive than competing technologies in south cities. Also, north Chinese cities are geographically more feasible for seawater heat pumps applications compared with south cities.
\end{abstract}

\section{Introduction}

According to International Energy Agency (IEA), residential buildings contribute to around $20 \%$ final energy demand worldwide, which is responsible for $22 \%$ of global carbon dioxide $\left(\mathrm{CO}_{2}\right)$ emissions [1]. As Duan et al. proved through Integrated Assessment Model based MultiModel Comparison, rapid development and implementation of renewable and sustainable energy technologies is the guarantee to achieve the $\mathrm{CO}_{2}$ emissions mitigation targets in Paris Climate Agreement and the warming-rise goal of $2{ }^{\circ} \mathrm{C}$ [2]. Therefore, heat pumps as a sustainable energy technology can play an important role in building space heating and space cooling sector at global level. At the European level, it is projected that heat pumps will cover $25 \%$ to $30 \%$ of district heating demand by 2050, which corresponds to 520TWh heating energy per year [3]. In China, direct use of fossil fuel in boilers and combined heat and power (CHP) still dominate the building heating sector. Replacing fossil fuel systems by heat pumps can save a large amount of energy and considerably cut the national pollutants emissions [4].

Seawater heat pump (SWHP) utilizes the energy in seawater to cover single building or building district's space heating, space cooling as well as domestic hot water demand. In winter, SWHP can pump heat from seawater to higher temperature suitable for space heating or domestic hot water supply. In summer, SWHP can use seawater as cold source for space cooling. SWHPs have been installed in many countries around the world, especially in Nordic countries where such installations are in large scale with several hundred kilowatt or even megawatt capacity. Sweden Ropsten area installed the world's largest SWHP system with a total capacity of $180 \mathrm{MW}$, which is coupled into local district heating system [5]. In Oslo, Norway, seawater is used as heat pump heat source during the cold period of the year and also for cooling purposes in summer [6]. In East Asia, Song et al. investigated the effects of utilizing SWHP for cooling purposes in a commercial complex, and found SWHP is more efficient than traditional air-source chillers [7]. The first seawater heat pump district heating and cooling project in

\footnotetext{
* Corresponding author.

E-mail address: changs@kth.se (C. Su).
} 


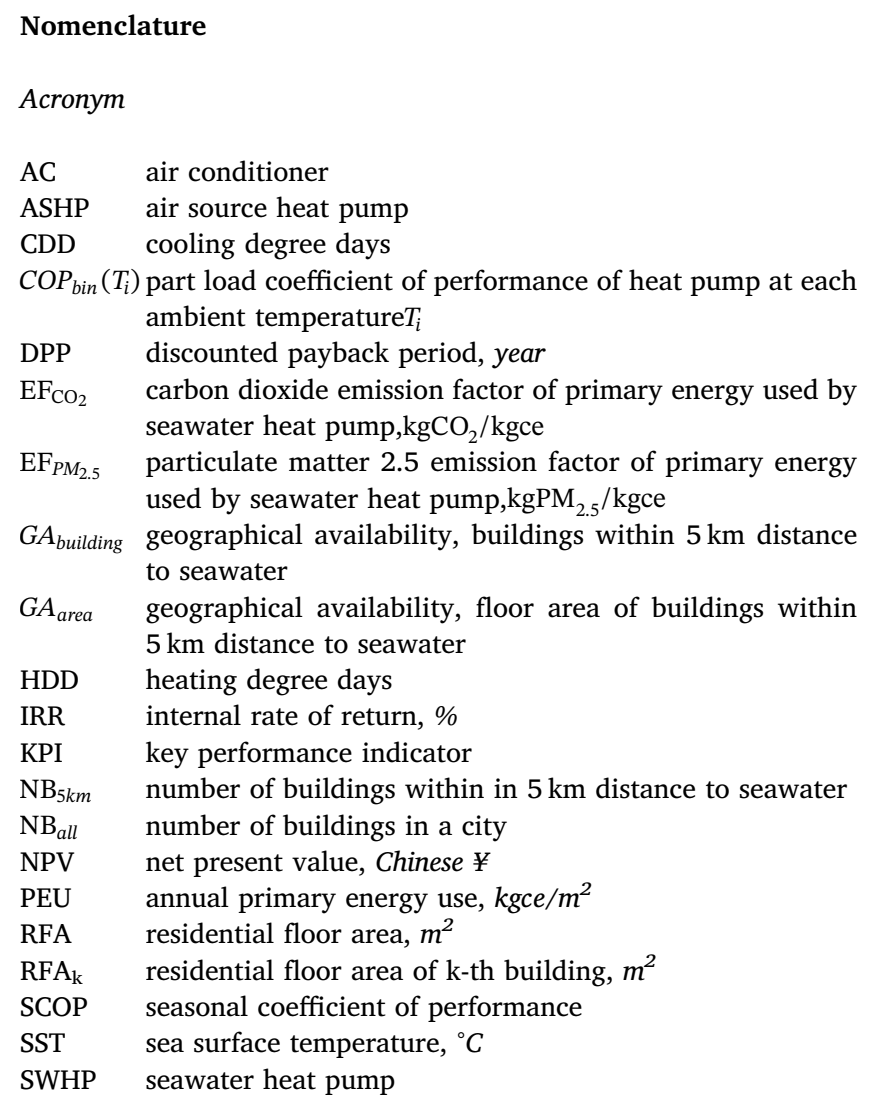

Greek

$\eta_{\text {gen }} \quad$ electricity generation efficiency

$\eta_{\mathrm{re}} \quad$ removal efficiency of emission control technologies

$\eta_{\text {tran }} \quad$ electricity grid transmission efficiency

Roman

\begin{tabular}{|c|c|}
\hline A & total building residential floor area, $m^{2}$ \\
\hline B & technology annual benefit, Chinese $¥$ \\
\hline $\mathrm{C}$ & technology annual cost, Chinese $¥$ \\
\hline$C_{\text {capital }}$ & capital cost of technology, Chinese $¥$ \\
\hline $\mathrm{E}_{\mathrm{CO}_{2}}$ & $\begin{array}{l}\text { carbon dioxide emission per square meter building re- } \\
\text { sidential floor area, } \mathrm{kgCO}_{2} / \mathrm{m}^{2}\end{array}$ \\
\hline $\mathrm{E}_{P M_{2.5}}$ & $\begin{array}{l}\text { particulate matter } 2.5 \text { emission per square meter building } \\
\text { residential floor area, } \mathrm{gPM}_{2.5} / \mathrm{m}^{2}\end{array}$ \\
\hline$f$ & $\begin{array}{l}\text { fossil fuel electricity percentage in total electricity con- } \\
\text { sumption }\end{array}$ \\
\hline$h_{i}$ & the number of hours at each ambient air temperature $T_{i}$ \\
\hline & $\begin{array}{l}\text { consequential number of bin hours at each ambient air } \\
\text { temperature }\end{array}$ \\
\hline ir & interest rate, $\%$ \\
\hline$j$ & consequential number of years \\
\hline$k$ & consequential number of building \\
\hline 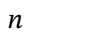 & life expectancy of technology, year \\
\hline$Q$ & building annual heating/cooling energy demand, $k W h$ \\
\hline$Q\left(T_{i}\right)$ & $\begin{array}{l}\text { the building heating/cooling load at each ambient tem- } \\
\text { perature } T_{i}, k W\end{array}$ \\
\hline $\sup \left(T_{i}\right)$ & $\begin{array}{l}\text { the supplementary heating/cooling provided by backup } \\
\text { devices, } k W\end{array}$ \\
\hline & ambient air temperature, ${ }^{\circ} \mathrm{C}$ \\
\hline
\end{tabular}

China had been constructed in Dalian city in north China. The total building floor area heated and cooled by SWHP in Dalian is 2.5 million $\mathrm{m}^{2}$ [8]. In Weihai city of north China, SWHP is installed for a large hotel with heating capacity of 2.2 MW [9]. Table 1 lists a non-exhaustive collection of SWHP installations throughout the world. In the table, coefficient of performance (COP) is reported to be annual SWHP system COP. Source temperature and supply temperature refer to seawater temperature at extraction inlet and condenser outlet temperature

Table 1

A non-exhaustive list of SWHP installations worldwide.

\begin{tabular}{|c|c|c|c|c|c|c|c|c|c|c|}
\hline Country & Project location & Refrigerant & $\begin{array}{l}\text { Total capacity } \\
\text { (MW) }\end{array}$ & $\begin{array}{l}\text { Heat pump } \\
\text { unit }\end{array}$ & $\mathrm{COP}$ & $\begin{array}{l}\text { Source water temp } \\
\left({ }^{0} \mathrm{C}\right)\end{array}$ & $\begin{array}{l}\text { Supply water temp } \\
\left({ }^{\circ} \mathrm{C}\right)\end{array}$ & Cooling & Operation since & Reference \\
\hline \multirow[t]{8}{*}{ Norway } & Horten & $\mathrm{NH}_{3}$ & 2.4 & 2 & 3.00 & 5 & 68 & Yes & 2012 & [3] \\
\hline & Drammen & $\mathrm{NH}_{3}$ & 13.2 & 3 & 3.05 & 8 & 90 & No & 2010 & [3] \\
\hline & Oslo & $\mathrm{R} 134 \mathrm{a}$ & 6.9 & 1 & 3.06 & 5 & 75 & Yes & 2006 & [3] \\
\hline & Oslo (Fornebu) & R134a & 6.8 & 1 & 3.06 & 5 & 75 & Yes & 2001 & [3] \\
\hline & Oslo (Fornebu) & R1234ze & 16 & 2 & 4.40 & & 75 & & 2012 & [10] \\
\hline & Oslo (Lysaker) & $\mathrm{R} 134 \mathrm{a}$ & 4.6 & 1 & 2.80 & & 75 & Yes & 2012 & [3] \\
\hline & Oslo (Lysaker) & $\mathrm{R} 134 \mathrm{a}$ & 4.6 & 1 & 2.80 & & 75 & Yes & 1999 & [3] \\
\hline & Trondheim & $\mathrm{R} 134 \mathrm{a}$ & 1.2 & 1 & 4.03 & 11 & 55 & Yes & & [3] \\
\hline \multirow[t]{5}{*}{ Sweden } & Stockholm (Ropsten) & R134a & 108 & 4 & 3.21 & 3 & 80 & Yes & 1986 & [11] \\
\hline & Stockholm (Ropsten) & $\mathrm{R} 134 \mathrm{a}$ & 48 & 2 & 2.86 & 3 & 80 & Yes & 1986 & [3] \\
\hline & Stockholm (Ropsten) & $\mathrm{R} 134 \mathrm{a}$ & 100 & 4 & 2.68 & 3 & 80 & Yes & 1986 & [3] \\
\hline & Åkersberga & $\mathrm{R} 134 \mathrm{a}$ & 6 & 2 & 3.20 & 7 to 18 & 83 & Yes & 1985 & [3] \\
\hline & Visby & $\mathrm{R} 134 \mathrm{a}$ & 11.5 & 1 & & & & No & 1983 & {$[3]$} \\
\hline \multirow[t]{2}{*}{ Denmark } & Copenhagen & $\mathrm{NH}_{3}$ & 5.2 & & & & & Yes & 2018 & [12] \\
\hline & Augustenborg & & 2 & & & & & Yes & 2016 & [12] \\
\hline Finland & Helsinki (Kartri Vala) & & 85 & 5 & & 10 & 62 & Yes & 2006 & [13] \\
\hline Italy & Divette (Cherbourg) & $\mathrm{R} 134 \mathrm{a}$ & 2.2 & 2 & 3.00 & 11 & 63 & No & 2013 & [3] \\
\hline Netherland & Hague & $\mathrm{NH}_{3}$ & 2.7 & & & 4 to 20 & 50 to 65 & Yes & 2014 & [14] \\
\hline \multirow[t]{2}{*}{ UK } & Anglesey & & & & 2.82 & & 55 & Yes & 2014 & [15] \\
\hline & Portsmouth & & & & & 6 & 50 & Yes & & [15] \\
\hline USA & Alaska & R134a & 0.6 & 2 & 3 & 3 to 13 & 49 & & & [16] \\
\hline Canada & Vancouver & & & & & & & Yes & & [17] \\
\hline \multirow[t]{4}{*}{ China } & Dalian (Xiaopingdao) & & 68 & & & & & & 2007 & [18] \\
\hline & Dalian (Xinghai) & $\mathrm{R} 134 \mathrm{a}$ & 25 & 3 & 3.35 & 3 & 65 & Yes & 2007 & [19] \\
\hline & Dalian (Xinghai) & & 10 & 1 & 3.52 & & & Yes & & [20] \\
\hline & Weihai & & 0.92 & 2 & 2.68 & 6 & 45 & Yes & 2010 & [21] \\
\hline
\end{tabular}


respectively. It can be noticed from the table that SWHPs are often installed in large scale, commonly with installed capacity from a minimum of $0.6 \mathrm{MW}$ to a maximum of $108 \mathrm{MW}$.

SWHP has several advantages. For example, using seawater as heating and cooling source, SWHP could reach a higher COP compared with air source heat pumps (ASHP) whose efficiency is significantly affected by ambient air temperature. Also, seawater can be used for cooling purposes during summer season without using the heat pump compressor and only with the liquid pumps on, which is called free cooling. Furthermore, when electricity comes from renewable sources such as wind or solar, SWHP can save greenhouse gas emissions as well as other air pollutants compared with fossil fuel based space heating. However, SWHP has its disadvantages when compared with other heating and cooling alternatives such as CHP, boilers, electric heaters or ground source heat pumps. For instance, SWHP suffers from high investment cost since a seawater source heat exchange system has to be installed. SWHP installation can only be limited to locations where seawater is available. Seawater temperature variation and water quality is also a concern for a successful SWHP application. Furthermore, the decision making criteria on which heating and cooling technology to choose can vary significantly depending on who makes the decision. For instance, Chinese government has committed to Kigali amendment and switching from fossil fuel based heating and cooling solutions to low environmental impact technologies [22]. Implementing SWHP in coastal areas could contribute greatly to achieve the national goals. At the same time, investors and city planners suffer from lack of understanding regarding the performances of SWHP systems from technoeconomic and environmental perspectives. In order to investigate the potential of implementing SWHP technology in different coastal geolocations of China, this paper first introduces a systematic method to evaluate the potential of SWHP from techno-economic, environmental as well as geographical perspectives based on spatial analysis, then presents case studies to show how to apply the method.

\section{Method}

The systematic method proposed in this paper ultimately builds an evaluation model to help different Chinese stakeholders on their decision makings about building space heating and space cooling solution choices - whether to install a SWHP or alternative technologies. Therefore, it is necessary to define system boundary as well as define level of model complexity. Fig. 1 displays the SWHP system viewed from three different levels of system boundaries as inspired by Lundqvist et al. [23].

System boundary 1 represents the thermodynamic cycle of SWHP unit which comprises a compressor, an evaporator, a condenser and an expansion valve. System boundary 2 expands from a SWHP unit to a SWHP system which further couples with the heating/cooling source and the heating/cooling sink. Here, heating/cooling source is seawater, heating/cooling sink is building. System boundary 3 is the energy system that considers the primary energy supply. As illustrated in Fig. 2(a), the potential evaluation of SWHP is carried out in all 3 system boundaries, which includes a SWHP unit sub-model, spatial source (seawater) sub-model, spatial sink (building) sub-model and spatial energy system sub-model.

The level of model complexity depends on the type of analysis carried out in the system. Modified from the suggested modelling complexity by Madani et al. [24], Fig. 2(b) provides an overview of finding the required model complexity. Both the SWHP system operation characteristics and building heating/cooling load characteristics are important. For example, at system boundary 2, seawater as energy source at different coastal cities should be investigated, including water temperature and water quality. Also at system boundary 2 , buildings at different spatial locations of China are under different climate conditions and have different envelope properties, so that transient building heating/cooling load and annual energy consumption is significantly different. To conclude, the model complexity of this study can be treated as lying somewhere at lower left corner of Zone A, where the main features of sub-models can be captured without consuming too much computation resources.

As mentioned, the exploitation of seawater energy using SWHP for building heating and cooling is related to many spatial data such as seawater temperature, seawater salinity, building properties etc., which requires spatial analysis. Spatial analysis is a set of techniques that analyses variables with physical dimensions and distributed in spaces. It is usually related to topological, geometric or geographic properties

System boundary 3

Primary energy sources

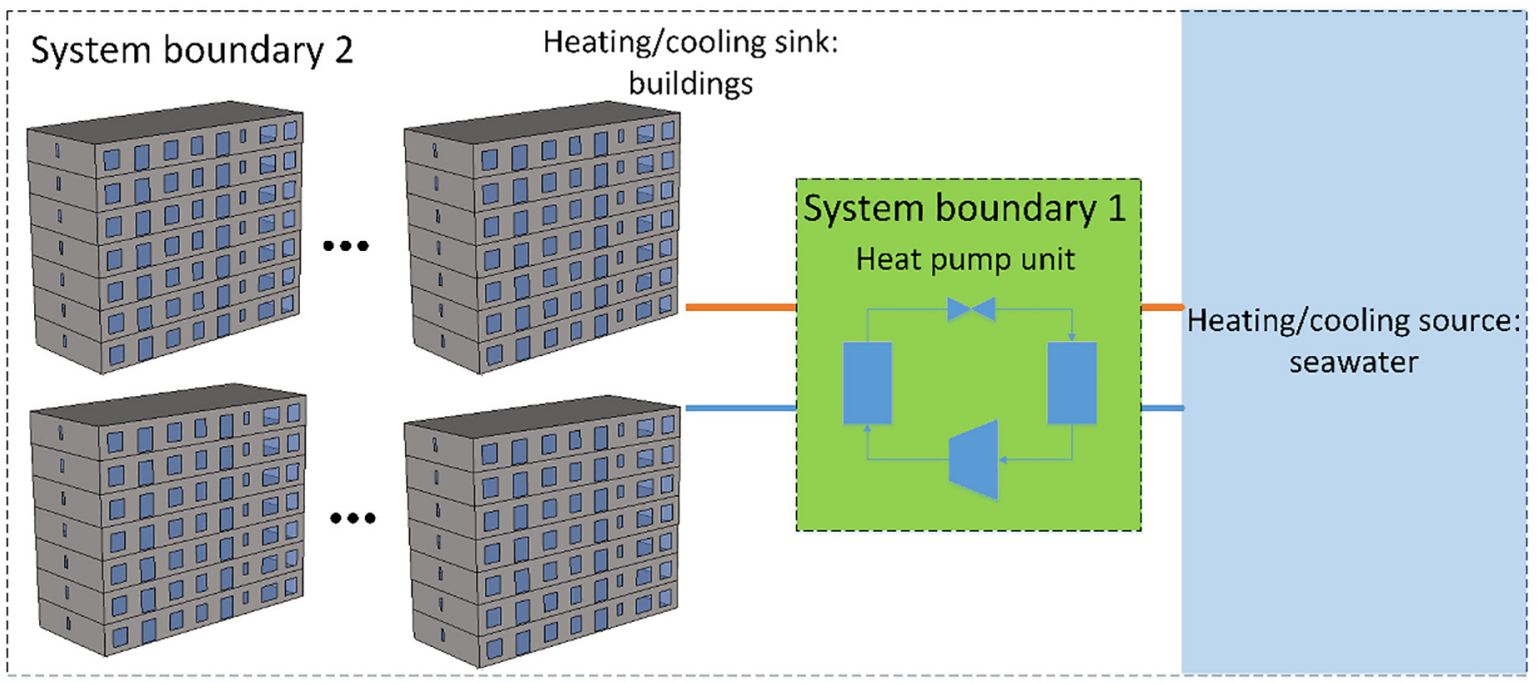

Fig. 1. System boundary for seawater heat pump potential spatial analysis. 


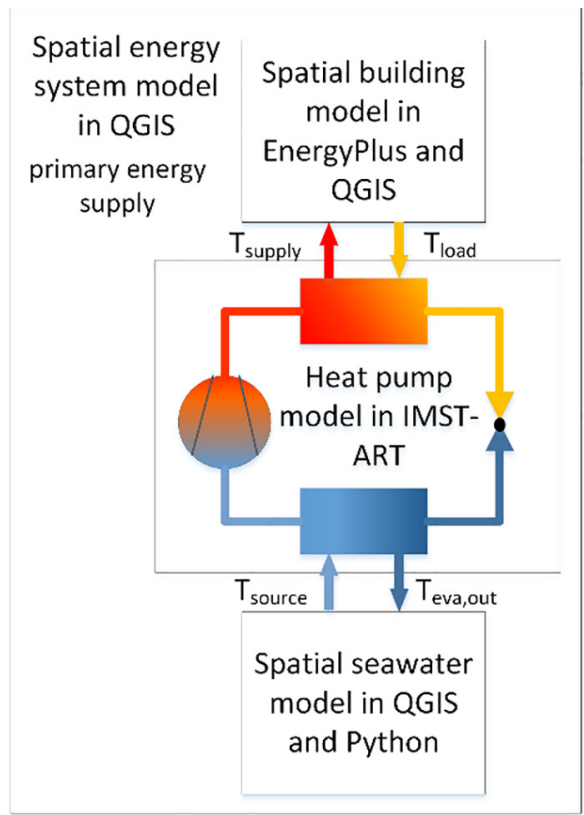

(a)
Very detailed model of

building heating/cooling

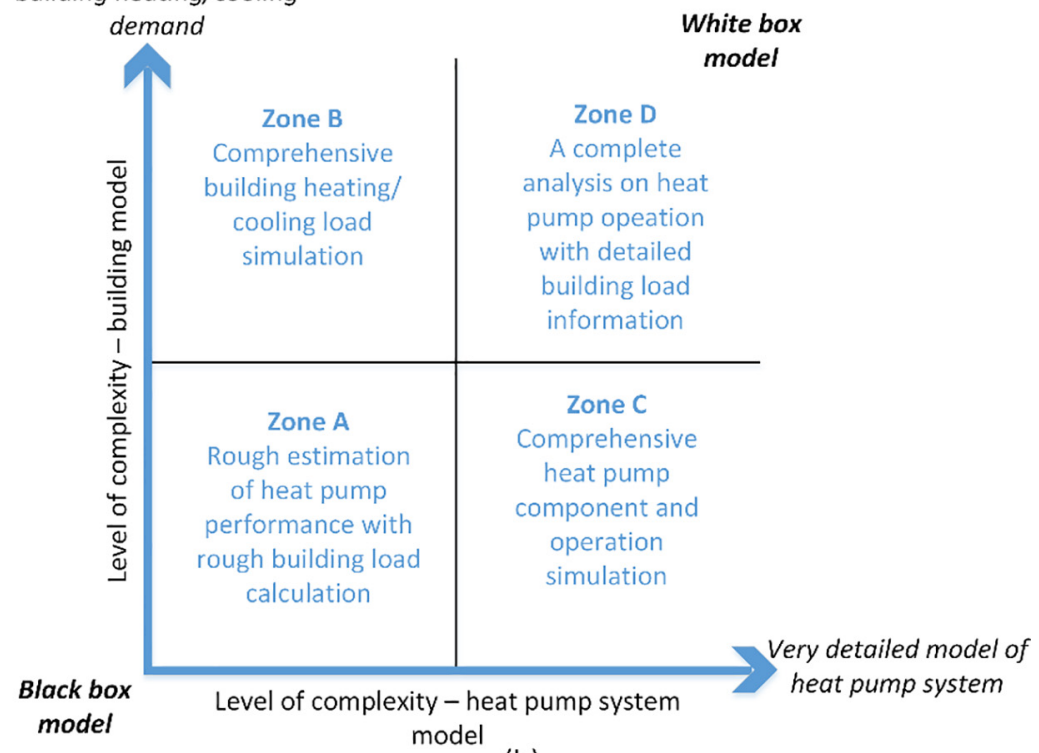

(b)

Fig. 2. (a) Illustration of model structure; (b) Roadmap of finding required model complexity.

[25]. Spatial analysis has been applied in energy field in many studies. For example, Lund and Persson mapped the potential heat sources for district heating heat pumps in Denmark considering the geographic correlation between heat source and heat load [26]. Wind energy potential is studied in [27] and [28] by using spatial inverse distance weight method. Spatial analysis is also used in finding solar power potential [29], hydro power potential [30] as well as geothermal potential [31]. Su et al. [32] investigated the feasibility of applying different building heating solutions in China using quantitative spatial analysis assisted by key performance indicator rating system. Assisted by spatial analysis, systematic evaluation method can provide insights of SWHP feasibility in different geolocations of China for various decision makers.
In this study, by analyzing spatial data in source (seawater), sink (buildings) and energy system, the techno-economic-environmental and geographical feasibility of SWHPs can be compared with status-quo space heating and cooling technologies. In order to quantitatively compare SWHPs' advantages and disadvantages over alternatives, a key performance indicator (KPI) system is suggested. The KPI system incorporates 8 indicators, which are technology efficiency, primary energy use (PEU) saving, discounted payback period (DPP), internal rate of return (IRR), $\mathrm{CO}_{2}$ emissions saving, particulate matter $2.5\left(\mathrm{PM}_{2.5}\right)$ emissions saving, as well as two indicators about SWHPs geographical availability. Though techno-economic analysis is common in comparing different technologies, and some papers consider $\mathrm{CO}_{2}$ emissions mitigation, it is rare to see a combination of all 8 mentioned KPIs. Also, this

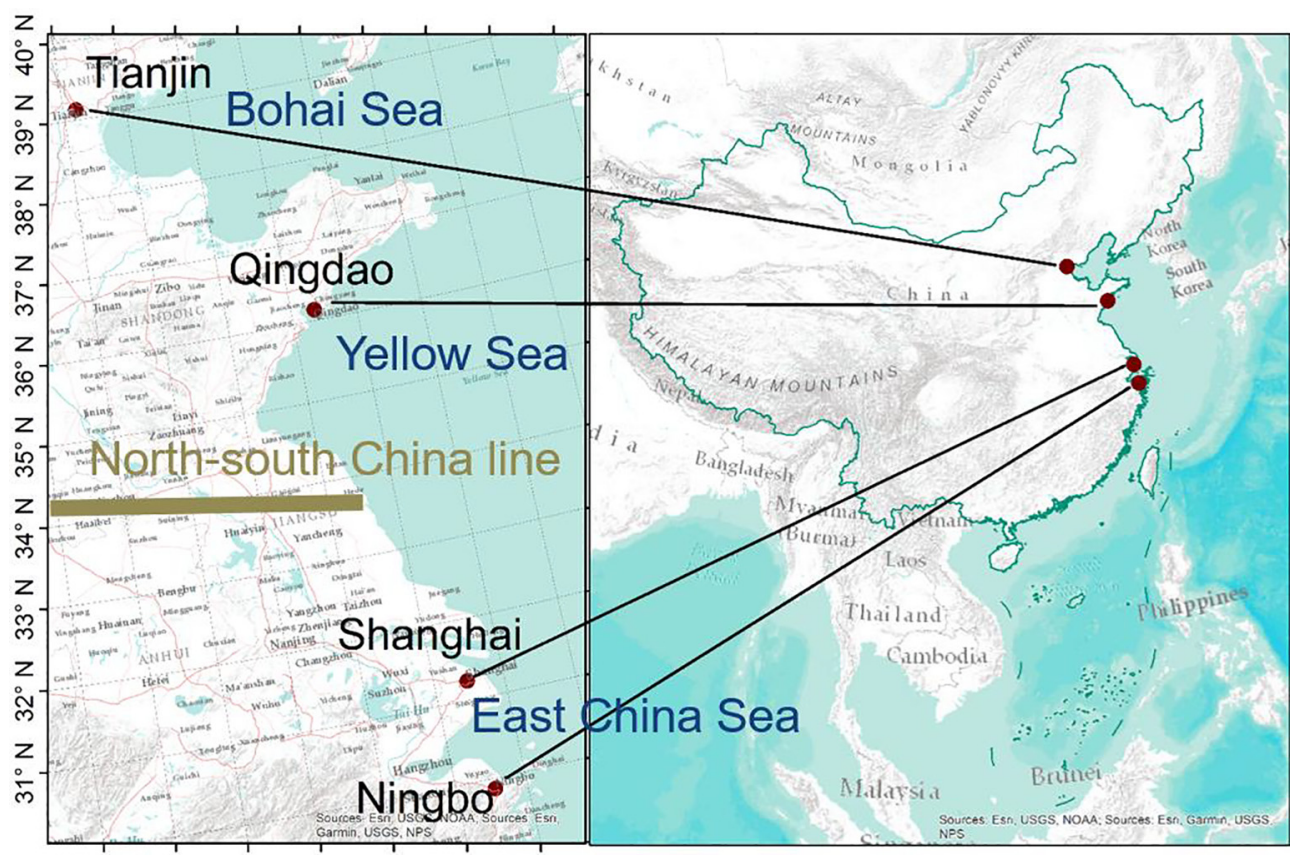

Fig. 3. Relative geolocation of case study cities. 
paper introduces $\mathrm{PM}_{2.5}$ emissions saving and innovative KPIs, geographical availability, to quantify geographical feasibility of using SWHPs in different coastal cities in China.

The proposed system approach is composed of three steps: spatial data collection, spatial data processing and KPIs calculation. Spatial data collection includes gathering source data (seawater), sink data (buildings), electricity driven SWHP operation data as well as energy system data such as local primary energy mix. Spatial data processing is carried out by using software such as QGIS. It re-structures collected raw spatial data into ready-to-use format as well as handles missing values. The calculation of KPIs are further explained in Section 4 of this paper.

\section{Case study}

In this paper, four coastal cities are selected for case study to evaluate SWHPs feasibility. They are Tianjin and Qingdao in north China, Shanghai and Ningbo in south China. Such choice is based on their geographical location variety, so that the influence of heterogeneous local spatial parameters, such as climatic conditions, seawater properties, resource availabilities as well as city configurations can be reflected by relative advantages and disadvantages. Also, local spatial data availability is another consideration, which includes seawater source data, climate data, building data, electricity mix data etc. The relative geolocation of these cities is shown in Fig. 3.

Located by the Bohai Sea in north China, Tianjin has a geographical coordinate of $39^{\circ} \mathrm{N}$ and $117^{\circ} \mathrm{E}$. It belongs to Cold climate zone of China, where buildings should fulfil local insulation regulations during winter. Located by the Yellow Sea in north China, Qingdao has a geographical coordinate of $36^{\circ} \mathrm{N}$ and $123^{\circ} \mathrm{E}$. It also belongs to the Cold climate zone of China. Shanghai $\left(31^{\circ} \mathrm{N}, 123^{\circ} \mathrm{E}\right)$ and Ningbo $\left(30^{\circ} \mathrm{N}, 122^{\circ} \mathrm{E}\right)$ are located by the East China Sea in south China. Both cities belong to Hot Summer Cold Winter climate zone of China. Buildings in such area should meet both summer ventilation and winter exterior wall insulation requirements.

\subsection{System boundary one: seawater heat pump unit model}

System boundary 1 describes the SWHP unit, which comprises four essential components: compressor, evaporator, condenser and expansion valve. In this specific study, SWHP operation data is obtained from simulation software IMST-ART [33]. The simulation data is derived from screw compressor heat pump units. The evaporators and condensers of heat pump units are assumed to be plate heat exchangers. Electronic expansion valve is used. The SWHP unit is a capacity controlled heat pump using both inverter and moveable slide in the screw compressor. Refrigerant used is R134a. Hence, obtained SWHP operation capacity and COP at different heat source-sink temperatures as well as simulation parameters are provided in Appendix A.

\subsection{System boundary two: source, sink and seawater heat pump system} model

As proposed in this paper, system boundary 2 incorporates heat source (seawater), heat sink (buildings) and SWHP system.

\subsubsection{Heat source: spatial seawater sub-model}

Seawater is the heat source for SWHP systems in heating mode. Important seawater parameters for a successful SWHP application are seawater temperature [34], seawater salinity [35], seawater intake method [36] as well as biofouling [37].

3.2.1.1. Seawater temperature. Seawater temperature is the prime parameter as the heat source of SWHP. In heating mode during winter, with a given building design indoor temperature, the higher the seawater temperature is, the higher the COP a SWHP can achieve. A SWHP system commonly exchanges heat with seawater which comes from certain depth of sea surface, cases range from 10 to $20 \mathrm{~m}$ for shallow depth application. At this depth, seawater has less diurnal temperature fluctuation compared with sea skin water, who is instantaneously affected by atmospheric air temperature, solar radiation and wind [38]. Fig. 4 illustrates the temperature gradient for general sea surface temperature (SST) where the exact definition of

\section{Temperature $\left({ }^{\circ} \mathrm{C}\right)$}

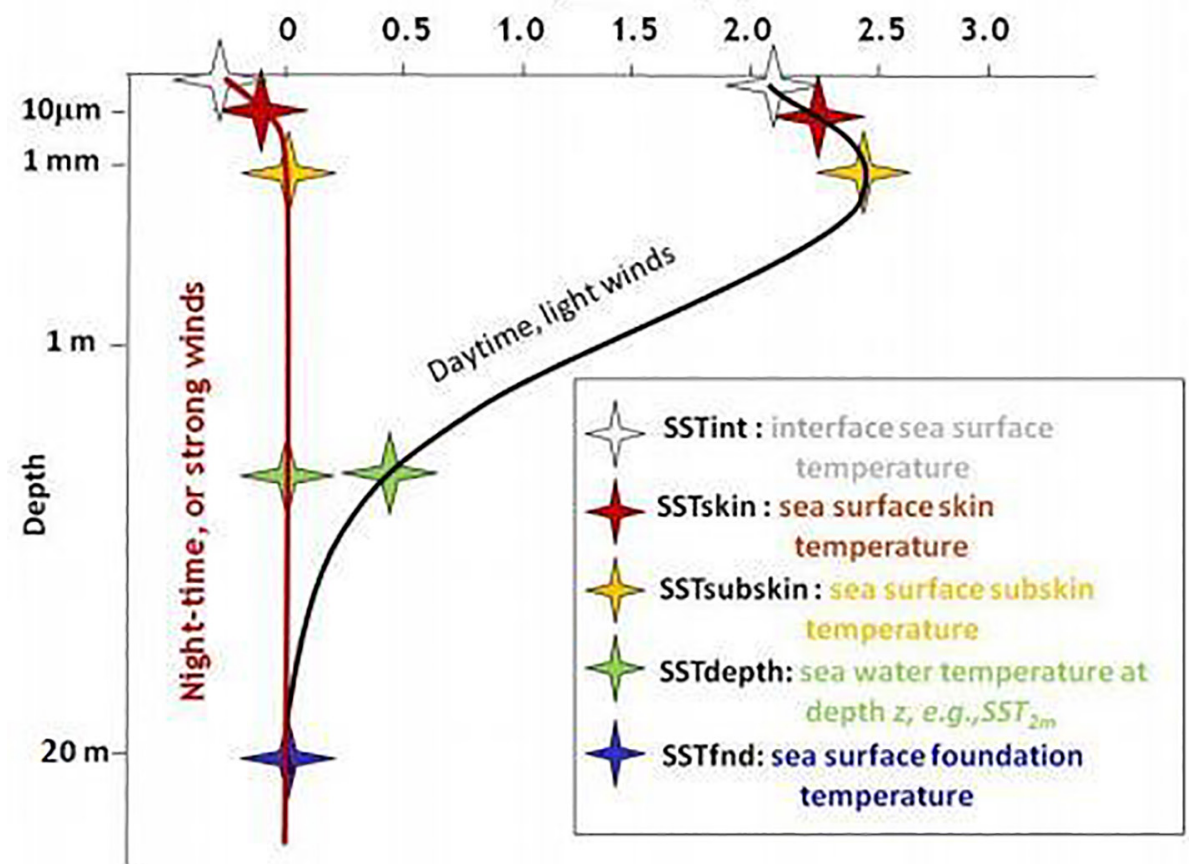

Fig. 4. Sea water temperature variation with increase of sea depth [41]. 
SST usually encompasses sea skin water temperature till a certain depth above $20 \mathrm{~m}$. Deeper seawater applications, for example intake seawater at $240 \mathrm{~m}$ in California [39] or $500 \mathrm{~m}$ depth in Honolulu [40], are only for cooling purposes in tropical or sub-tropical areas, where seawater temperature extracted can be as low as $5{ }^{\circ} \mathrm{C}$.

This paper chooses $15 \mathrm{~m}$ depth seawater as heat source for SWHP and assumes that SWHP covers both full heating and cooling demand of buildings without backup devices needed. The seawater temperature data is retrieved from Asia Pacific Data Research Center's Live Access Server [42], which was initiated in the year of 1989 [43]. The geographical and seasonal variations of seawater temperature at $15 \mathrm{~m}$ depth of case study cities are displayed in Fig. 5. Fig. 5(a) displays seawater geographical variation due to changes of latitude. Lower latitude seas have higher average temperature than that of higher latitude seas. Fig. 5(b) indicates that seawater seasonal variation lags behind ambient air temperature and seawater has less temperature fluctuation compared with air temperature.

3.2.1.2. Seawater salinity. Seawater is a complex solution of many salts. The presence of salt is the major reason for corrosion through the electrochemical corrosion process [44]. Metallic components that direct contact seawater, such as heat exchangers, liquid pipelines and liquid pumps need to be made by corrosion resistant materials such as titanium, nickel-based alloys or stainless steel alloys. However, due to the high cost of such materials, researchers have been trying to find non-metallic materials such as thermoplastics to substitute metallic seawater heat exchangers [45].

The seawater salinity varies in different spatial locations of China. As shown in Fig. 6, salinity in Tianjin coast (Bohai Sea) is on average 3.3\%, higher than Qingdao 3.0\% (Yellow Sea), Shanghai 2.6\% (East China Sea) and Ningbo $2.8 \%$ (East China Sea). The seawater salinity in China seas is 1.5 times to 2 times higher than Baltic Sea in North Europe. Researches have proved that salinity around 3\% is most corrosive [46], so more corrosion precautions should be used in China compared with North European countries. Usually titanium heat exchanger is used, which can be 2 to 3 times more expensive than heat exchangers made from other metallic materials [47]. Extra protection cost will increase maintenance cost of SWHP systems in China.

Tests have shown that seawater salinity has very limited influence

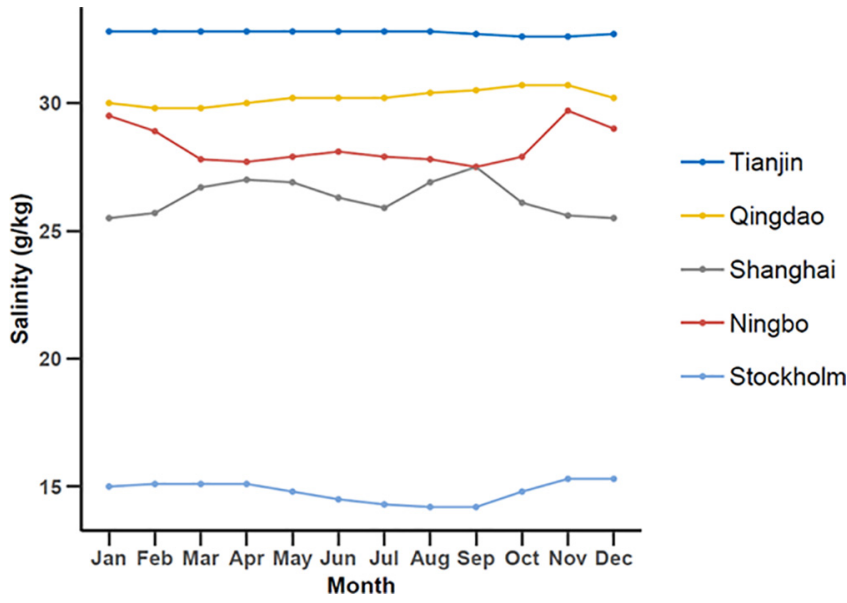

Fig. 6. Seawater salinity geographical and seasonal distribution [48].

on its viscosity and consequent pumping power. Ignatowicz et al. proved that when seawater salinity varies from $0.0 \%$ to $3.5 \%$, the changes of viscosity is less than $5 \%$, so the salinity do not significantly increase pumping power [49].

3.2.1.3. Seawater intake method. Seawater intake method can be categorized into open-loop or closed-loop system. Open-loop system transports fresh seawater to heat pump unit heat exchangers, then reject it back to the sea. For closed-loop system, a closed brine loop is added between the sea and the heat pump unit, so that heat pump unit exchanges heat with the brine. Sometimes a beach well can be drilled and infiltrated seawater is used. It is found that such beach well infiltration SWHP system has a higher COP value [50], since the infiltrated water temperature is $2^{\circ} \mathrm{C}$ warmer than seawater in winter and $2{ }^{\circ} \mathrm{C}$ lower than seawater in summer [35]. The schematics of different configurations of SWHP seawater intake methods are shown in Fig. 7.

3.2.1.4. Seawater biofouling. For SWHP application, especially in cooling mode during summer, the seawater temperature can reach

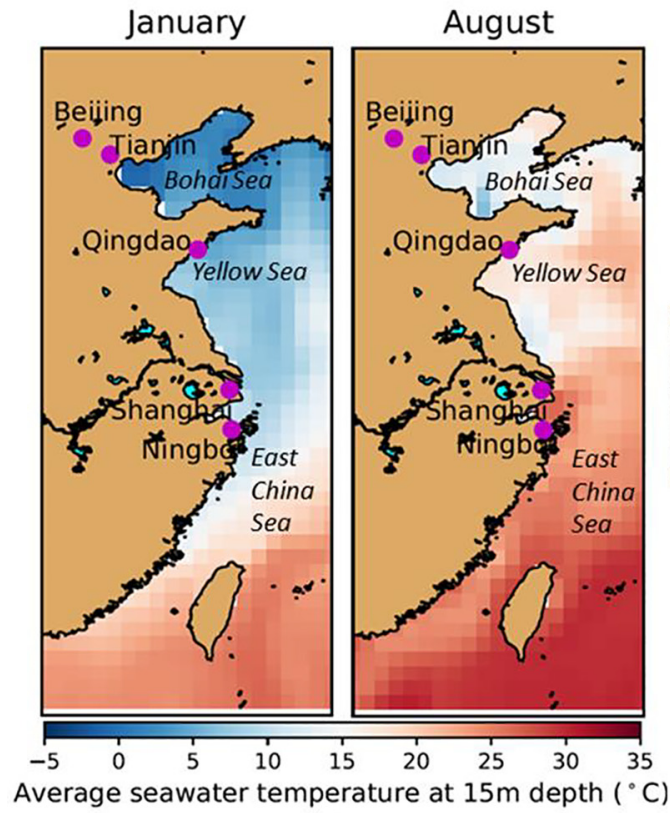

(a)

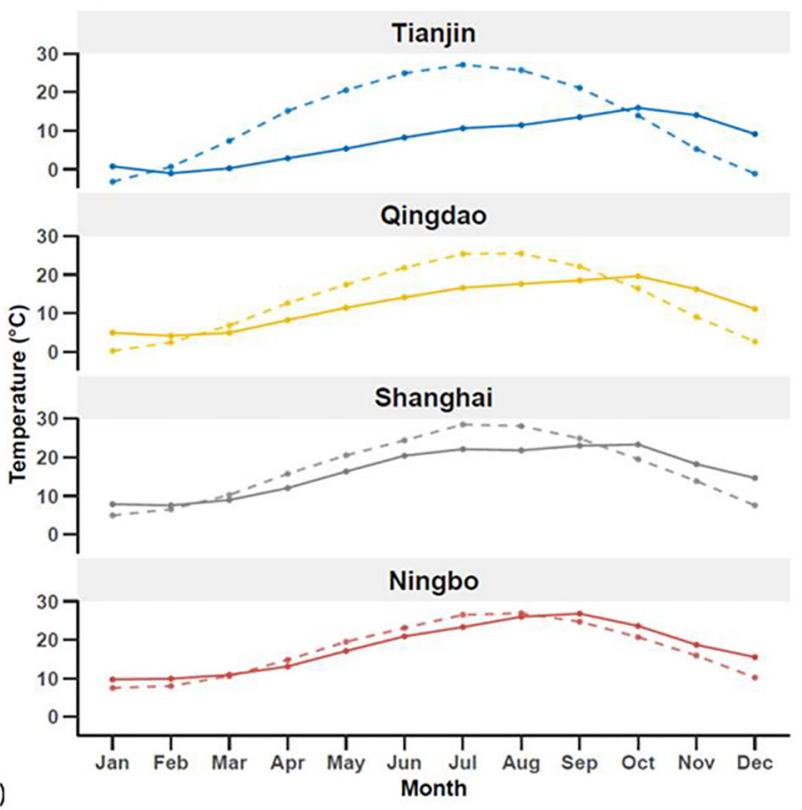

(b)

Fig. 5. Seawater temperature geographical and seasonal distribution ( $15 \mathrm{~m}$ depth). 

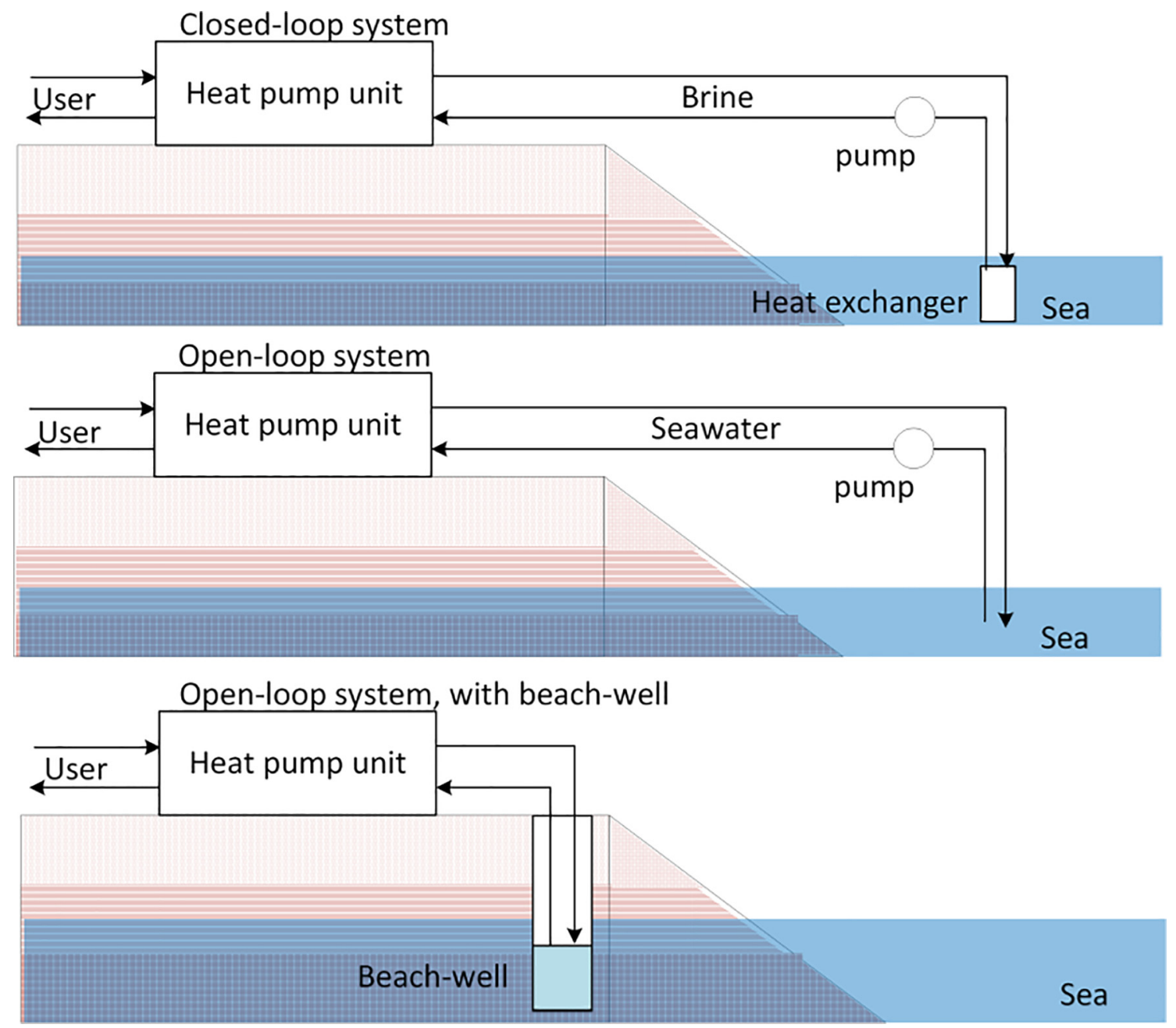

Fig. 7. SWHP system seawater intake methods.

$25^{\circ} \mathrm{C}$ or higher, which is a warm incubator for sea organisms. The planktonic microorganisms can develop a biofilm attached to the inside or outside of pipelines or heat exchangers that contact the seawater, which consequently lead to biofouling. Significant negative effects on SWHPs application from biofouling include the blockage of water free flow and consequent mechanical damage to pumps, clogging of water tubes as well as reduction of the heat transfer efficiency. Furthermore, biofouling can lead to the microbiologically influenced corrosion on metal surfaces due to the change of electrochemical properties of metalwater interface.

For a successful SWHP application, biofouling should be prevented. Several methods are used: physical screening, physical cleaning and chemical dosing [37]. Physical screening refers to using high pressure water flow to flush away macrofouling or bio-settlements attached to SWHP pipelines and heat exchangers. Then, physical cleaning can be used such as using sponge rubber balls to remove biofilms. Except for mechanical cleaning, associated chemical treatments are needed such as by using biocides [51]. Currently, chlorination is still the most common biocide to control biofouling. But chlorination has harmful effects to the aquatic environment and human health due to the chlorination by-products. So chlorination treatments have to be carried out intermittently in order to keep chlorine residuals at a low level of 0.3-0.5 ppm [52].

\subsubsection{Heat sink: building model}

The building space heating and space cooling demand depend on climatic conditions and building design properties, which also varies spatially from north to south in China. Shown in Fig. 8 represented by degree days, the heating degree days (HDD) and cooling degree days (CDD) reflects how much heat or cold energy should be supplied to the building during winter or summer seasons.

For case study cities, it can be seen from Fig. 8 that Tianjin has harsh winters and relatively hot summer, so Tianjin has a relatively balanced heating and cooling demand. Qingdao has a cold winter and enjoys a mild summer under the influences of Yellow Sea. So the buildings in Qingdao is heating dominated. Coastal cities alongside East China Sea are mostly dominated by cooling demand, as represented by Shanghai and Ningbo.

In the building model, a simplified 7 stories residential multi-family house is set up as reference building. A total of 10 reference buildings formed a representative building district. The total building floor area of the district is 17.6 thousand $\mathrm{m}^{2}$. Building space heating and space cooling peak demand and annual demand are simulated using EnergyPlus [53]. Then a SWHP is sized to meet peak heating and cooling demand. Detailed building load simulation parameters, including design climate conditions, thermal zones, building construction materials etc. are provided in Appendix B. Choices of building envelope materials, windows etc. is based on case study cities' local building energy efficiency design standards in Tianjin [54], Qingdao (in Shandong Province) [55], Shanghai [56] and Ningbo (in Zhejiang Province) [57]. Design indoor temperature for heating is set to be $18^{\circ} \mathrm{C}$, whereas design indoor temperature for cooling is set to be $26^{\circ} \mathrm{C}$ according to Chinese standard [58]. Simulation results of reference building peak load as well as annual energy demand for case study cities are listed in 

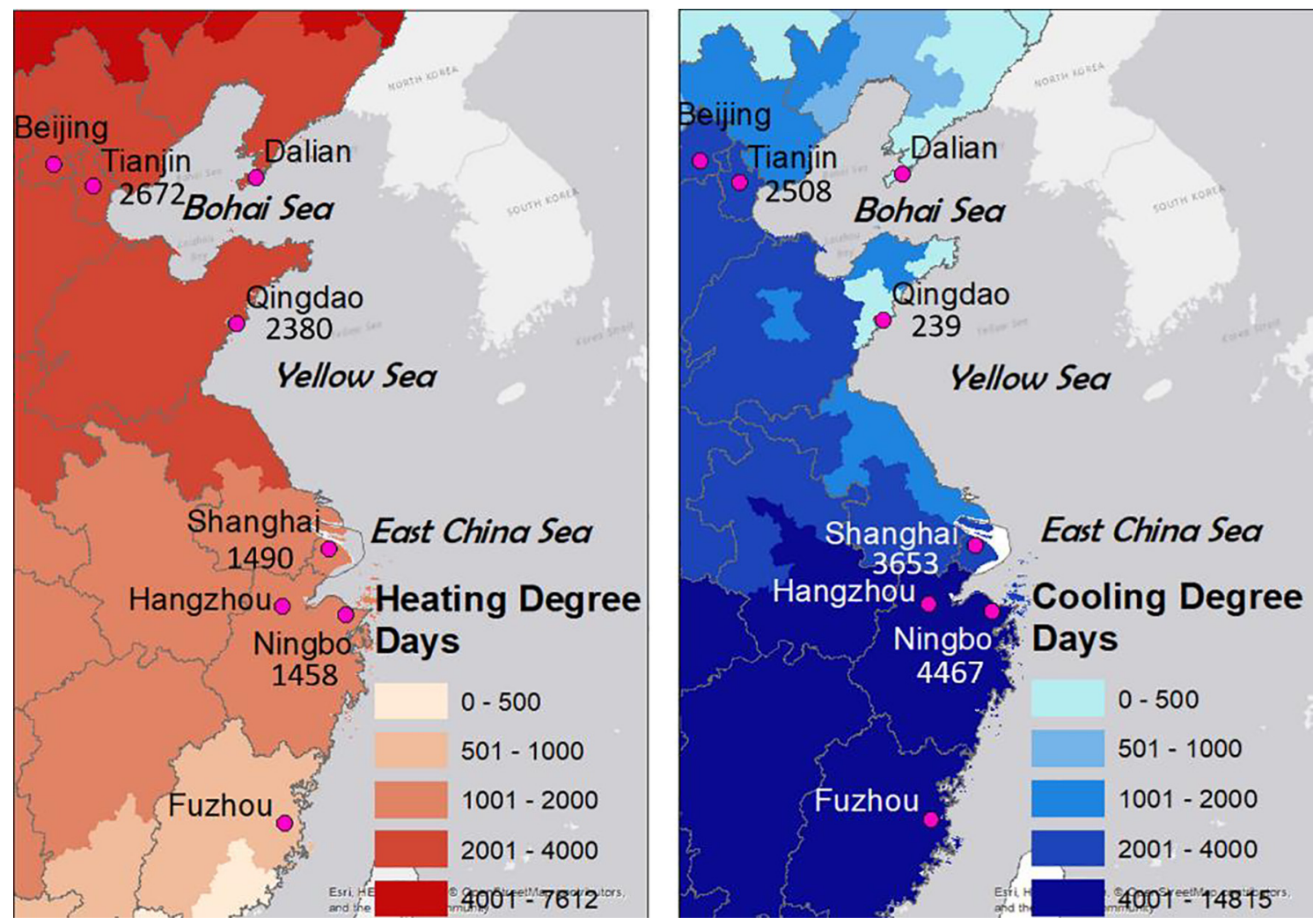

Fig. 8. Heating and cooling degree days for parts of coastal areas of China.

Table 2

Building peak load and annual energy demand simulation results.

\begin{tabular}{lllll}
\hline City & Peak heating & Peak cooling & Heating intensity & Cooling intensity \\
\hline Tianjin & $48 \mathrm{~kW}$ & $48 \mathrm{~kW}$ & $34 \mathrm{kWh} / \mathrm{m}^{2}$ & $28 \mathrm{kWh} / \mathrm{m}^{2}$ \\
Qingdao & $43 \mathrm{~kW}$ & $43 \mathrm{~kW}$ & $31 \mathrm{kWh} / \mathrm{m}^{2}$ & $20 \mathrm{kWh} / \mathrm{m}^{2}$ \\
Shanghai & $50 \mathrm{~kW}$ & $76 \mathrm{~kW}$ & $24 \mathrm{kWh} / \mathrm{m}^{2}$ & $35 \mathrm{kWh} / \mathrm{m}^{2}$ \\
Ningbo & $58 \mathrm{~kW}$ & $85 \mathrm{~kW}$ & $28 \mathrm{kWh} / \mathrm{m}^{2}$ & $43 \mathrm{kWh} / \mathrm{m}^{2}$ \\
\hline
\end{tabular}

Table 2, which can be cross validated with [59] and [60].

\subsubsection{Seawater heat pump system}

In this model, since seawater in Tianjin is close to or below $0{ }^{\circ} \mathrm{C}$ in January, February, March and April, indirect seawater intake system has to be used to prevent freezing in heat pump evaporator during space heating seasons. A closed brine loop is added between SWHP evaporator and seawater. In the brine loop, the secondary fluid of ethyl alcohol with mass weight of $25 \%$ circulates, whose freezing temperature is around $-15{ }^{\circ} \mathrm{C}$. For a fair comparison, indirect system is also assumed for Qingdao, Shanghai and Ningbo. Then corrosion resistive plastics are used for heat exchangers that submerged into the seawater of $15 \mathrm{~m}$ deep, so that corrosion problems can be neglected. Biofouling is considered in maintenance cost. The indoor terminals for space heating are assumed to be radiators, so water supply and return temperature is set to be $45^{\circ} \mathrm{C}$ and $40^{\circ} \mathrm{C}$. Indoor terminals for space cooling are assumed to be fan-coil units if central cooling is used. The supply and return water temperature is $7^{\circ} \mathrm{C}$ and $12^{\circ} \mathrm{C}$.

\subsection{System boundary three: energy system model}

In the energy system model, local primary energy mix for electricity grid is decided for electricity driven vapor compression SWHP systems. The primary energy source for electricity is important, because it influences emission savings of SWHP. For the four case study cities, primary energy mix for electricity gird is decided based on provincial or

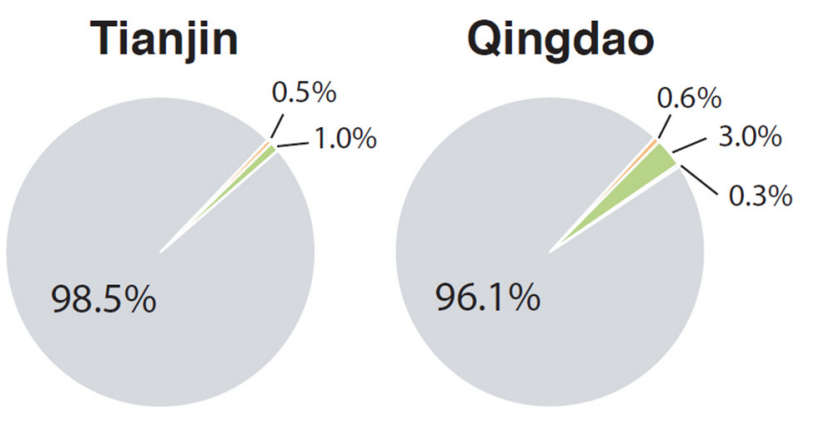

\section{Shanghai}

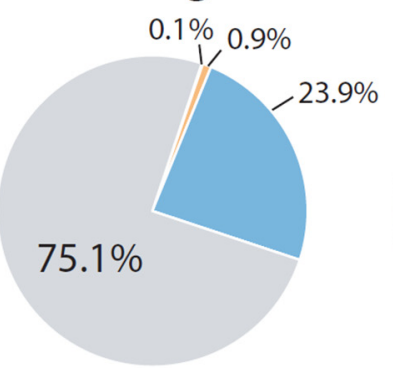

Wind
Solar
Ningbo

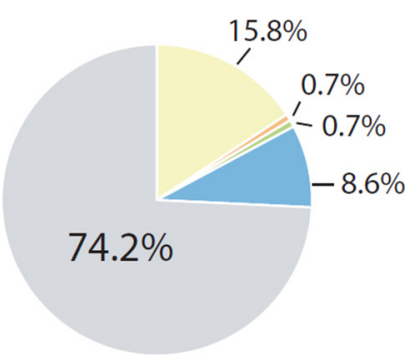

Coal Hydro Wind

Fig. 9. Primary energy mix for local electricity grid [61]. 
regional grid characteristics, which is displayed in Fig. 9.

\section{Seawater heat pump potential evaluation key performance indicators}

In this study, a four dimensional KPI system is established to evaluate SWHP feasibility quantitatively in Tianjin, Qingdao, Shanghai and Ningbo. They are technical KPIs (SCOP and PEU saving), economical KPIs (DPP and IRR), environmental KPIs $\left(\mathrm{CO}_{2}\right.$ and $\mathrm{PM}_{2.5}$ emissions saving) and geographical KPIs. SWHP is compared with status-quo building space heating/cooling technologies. Relative advantages and disadvantages by using SWHP over status-quo technologies can be reflected by selected KPIs. The choice of status-quo building heating/ cooling technologies is based on current status evaluated in [32]. Tianjin and Qingdao use central boiler and split air-conditioners as status-quo system, while Shanghai and Ningbo use central ASHP as status-quo system.

\subsection{Technical key performance indicators}

System efficiency of heat pumps during a whole heating/cooling season is evaluated by seasonal coefficient of performance (SCOP). It matters when comparing different types of heat pumps or when comparing heat pumps with alternative building heating/cooling technologies. In this paper, SCOP is calculated based on EN-14825 method [62], since currently there's no similar Chinese standard can be referred to. (See Eq. (1)).

$S C O P=\frac{\sum_{i=1}^{8760} h_{i} \times\left[Q\left(T_{i}\right)-\sup \left(T_{i}\right)\right]}{\sum_{i=1}^{8760} h_{i} \times\left[\frac{Q\left(T_{i}\right)-\sup \left(T_{i}\right)}{\operatorname{COP}_{\text {bin }}\left(T_{i}\right)}\right]}$

In this study, both SWHP and ASHP are assumed to cover full building heating/cooling load, so no supplementary heating/cooling is considered $\left(\sup \left(T_{i}\right)=0\right)$. Electricity consumption of circulation pump is assumed to account for $25 \%$ of total heat pump system electricity consumption according to [63]. For coal boilers, system efficiency is set to be 0.75 according to [64]. Fossil fuel primary energy use (mainly coal in China) of heat pumps is calculated by Eq. (2). The choice of $f$, $\eta_{\text {tran }}, \eta_{\text {gen }}$ are according to [61] for four cities.

$P E U_{H P f o s s i l}=\frac{f \times Q}{S C O P \times \eta_{\text {tran }} \times \eta_{\text {gen }} \times A}$

\subsection{Economic key performance indicators}

DPP can provide an evaluation of payback time of a certain investment taking into account of the time value of investment money. IRR can show how profitable to invest on a certain technology on life cycle basis. Eqs. (3) and (4) is used to calculate DPP and IRR. Interest rate (ir) is chosen to be $3.1 \%$ according to [65].

$D P P=\frac{\ln (B-C)-\ln \left(B-C-i r \times C_{\text {capital }}\right)}{\ln (1+i r)}$

$N P V=\sum_{i=1}^{n} \frac{B_{i}-C_{i}}{(1+I R R)^{i}}-C_{\text {capital }}=0$

According to capital cost and operation maintenance cost data obtained by [32], cash flow diagram of SWHP system with status-quo system can be obtained. Descriptions of how economic values are obtained and price setting for different technologies are provided in Appendix C.

\subsection{Environmental key performance indicators}

Environmental KPIs include $\mathrm{CO}_{2}$ emissions and $\mathrm{PM}_{2.5}$ emissions. $\mathrm{CO}_{2}$ emissions link to China's Nationally Determined Contributions towards United Nations Sustainable Development Goals. It also relates to China's commitment to Kigali amendment. $\mathrm{PM}_{2.5}$ emissions reflect SWHPs' potential in combating air pollution problems during recent years. Calculation method is referred to IPCC emission inventory calculation method [66]. Data sources used to calculate environmental KPIs are provided in [67]. $\mathrm{CO}_{2}$ emissions and $\mathrm{PM}_{2.5}$ emissions for operating different technologies are determined in Eqs. (5) and (6).

$E_{\mathrm{CO}_{2}}=\frac{E F_{\mathrm{CO}_{2}} \times P E U}{A}$

$E_{P M_{2.5}}=\frac{E F_{P M_{2.5}} \times P E U \times\left(1-\eta_{r e}\right)}{A}$

\subsection{Geographical key performance indicators}

Two innovative geographical KPIs, geographical availability of buildings $\left(G A_{\text {building }}\right)$ and geographical availability of building floor areas $\left(G A_{\text {area }}\right)$, are proposed in this study. Since SWHPs' application is geographically constrained, only buildings within a certain distance to the seawater can utilize it as heat/cold source. A long distance to transport seawater will lead to excessive circulation pump electricity consumption. Lund et al. considers that buildings within $500 \mathrm{~m}$ to seawater body have potential to install a SWHP [26]. This can be regarded for individual or maximum a few buildings' SWHP installation. However, for district heating level where transportation distance is much longer, Shu et al. studied optimal district heating radius for SWHP when compared with traditional coal boiler district heating system in China, and found that SWHP is more energy efficient only within a radius of $5 \mathrm{~km}$ compared with coal boiler system [68]. Since only limited number of studies have discussed optimal distance of utilizing seawater as energy source for heat pumps, this paper defines that buildings within $500 \mathrm{~m}$ to seawater have geographical potential to use SWHP for individual heating and cooling, building district within $5 \mathrm{~km}$ to seawater has geographical potential to use SWHP in district heating and cooling level. Hence, $G A_{\text {building }}$ evaluates the number of buildings within $5 \mathrm{~km}$ distance to seawater, which is calculated by equation (see Eq. (7)). Whereas $G A_{\text {area }}$ calculates total residential floor area of buildings within $5 \mathrm{~km}$ to seawater (see Eq. (8)), which can give the idea of how much is the total residential floor areas that can be heated/ cooled by using SWHP. These two KPIs can help building contractors or city planners evaluate how many buildings or building districts in a city can consider install a SWHP when it comes to the choice of building heating and cooling solutions.

$G A_{\text {building }}=\frac{N B_{5 \mathrm{~km}}}{N B_{\text {all }}}$

Table 3

Technical potential of seawater heat pump relative to status-quo system.

\begin{tabular}{|c|c|c|c|c|c|c|c|c|}
\hline \multirow[t]{2}{*}{ Relative improvement } & \multicolumn{2}{|l|}{ Tianjin } & \multicolumn{2}{|l|}{ Qingdao } & \multicolumn{2}{|l|}{ Shanghai } & \multicolumn{2}{|l|}{ Ningbo } \\
\hline & Heating & Cooling & Heating & Cooling & Heating & Cooling & Heating & Cooling \\
\hline System efficiency & $165 \%$ & $89 \%$ & $182 \%$ & $26 \%$ & $13 \%$ & $2 \%$ & $17 \%$ & $-5 \%$ \\
\hline PEU saving (coal) & $18 \%$ & $43 \%$ & $19 \%$ & $20 \%$ & $11 \%$ & $2 \%$ & $14 \%$ & $-6 \%$ \\
\hline
\end{tabular}


$G A_{\text {area }}=\sum_{k=1}^{n} R F A_{k}$

\section{Results and discussion}

Results of KPIs calculation and discussions on SWHP feasibility in case study cities are presented in this section.

\subsection{Technical potential of seawater heat pump}

Results of SWHPs' technical KPI improvements relative to status-quo system are listed and compared in Table 3.

It can be seen from Table 3 that for Tianjin and Qingdao, when compared with coal boiler space heating, the efficiency (SCOP) of SWHP is $165 \%$ and $182 \%$ higher than boiler. By comparing SWHP with split AC in space cooling, the SWHP is $89 \%$ and $26 \%$ more efficient. In south China of Shanghai and Ningbo, when compared with ASHP in space heating, the SCOP of SWHP is $13 \%$ and $17 \%$ higher than that of ASHP. In cooling mode, the SCOP of SWHP is $2 \%$ higher than SCOP of ASHP in Shanghai, but SWHP SCOP is 5\% lower than ASHP SCOP in Ningbo. This shows the seawater temperature in Ningbo is a disadvantage for SWHP application in space cooling. Especially when a closed-loop system is used, the added brine loop between the SWHP condenser and the seawater heat sink increases SWHP losses in the system, which decreases its SCOP.

For Tianjin and Qingdao in space heating, PEU of SWHP is compared with PEU of coal boiler, so the PEU saving is reflected by primary coal saving. In these two cities, primary coal saving by using SWHP instead of coal boiler is $18 \%$ and $19 \%$ respectively. It implies that despite SWHP system has a much higher system efficiency compared with coal boiler in building space heating, its PEU saving, which reflected by primary coal saving in this case, may not have the same scale.

PEU saving could be influenced by several factors: the coal power plants' generation efficiency, the power grid's transmission efficiency, the zero-carbon electricity share in power grid as well as the SWHP SCOP. If the coal power plants' generation and power grid's transmission efficiency is low, for a given SWHP, its primary coal saving compared with direct burning fossil fuel for space heating is less apparent. This could be true for some remote villages where electricity grid loss can be as high as $20 \%$. Since most coastal settlements in China are in well-developed East and South region, the electricity generation and transmission loss has insignificant effect on SWHP PEU saving.

Increasing zero-carbon electricity share in power grid can increase SWHP's primary coal saving. For example, shown in Fig. 10, for Tianjin where currently $98 \%$ electricity is from coal-fired power plants, the primary coal saving by using SWHP instead of coal boiler is $28 \%$. By increasing zero-carbon electricity share, primary coal saving increases. Of course, when the grid system reaches $100 \%$ renewable, the primary coal use can be avoided for SWHP systems where the corresponding primary coal saving is $100 \%$. Alternatively, installing a more efficient SWHP could also save more fossil PEU saving compared with coal boiler. Again as shown in Fig. 10 when SWHP SCOP increases from 2.8 to 3.6 , its primary coal saving increases from $26 \%$ to $46 \%$.

For Shanghai and Ningbo, where SWHP and ASHP electricity consumption comes from the same grid, SWHP's PEU saving compared to ASHP is mainly up to SWHP's SCOP. As SWHP's SCOP is about $13 \%$ better than ASHP in Shanghai, its PEU saving to ASHP is around 11\%. For space cooling in Ningbo, where SCOP of SWHP is lower than ASHP, its PEU saving is therefore negative. In general, SWHP shows higher technical potential in Tianjin and Qingdao than Shanghai and Ningbo when compared with respective status-quo system under current status.

\subsection{Economic potential of seawater heat pump}

Results of DPP and IRR are shown in Fig. 11. The DPP of Tianjin and
Qingdao is 12.9 year and 3.7 year respectively. The IRR of Tianjin and Qingdao is 5\% and 28\% respectively. The DPP of Shanghai is 11.4 year and DPP of Ningbo is more than 15 years, so the corresponding IRR is $6 \%$ and negative value. This shows SWHP system is more economically feasible in Qingdao when compared with status-quo configuration, where SWHP's operating cost is much lower than boiler and air-conditioners. In Tianjin, Shanghai and Ningbo, however, SWHP does not show economic attractiveness compared with status-quo system, as SWHP's operation cost is not significantly cheaper.

Through sensitivity analysis, it can be found that in Tianjin and Qingdao when SWHP is compared with coal boiler and air-conditioners, the reduction of SWHP cost does not effectively reduce its DPP. On contrary, In Shanghai and Ningbo when SWHP is compared with ASHP, the reduction of SWHP cost can greatly shorten its DPP. For example in Shanghai, when SWHP capital cost is reduced by $5 \%$, the DPP shortens from 11.4 year to 5.6 year. If SWHP capital cost is further reduced by $10 \%$, the DPPs can even reach 1.8 year and the corresponding IRR is $59 \%$. It shows that the influence of SWHP's cost on its economic potential is more prominent in Shanghai and Ningbo of south China. Therefore, in the future when SWHP technology further develops and its cost reduces, SWHP will have more economic potential in Shanghai and Ningbo compared with Tianjin.

\subsection{Environmental potential of seawater heat pump}

Results of $\mathrm{CO}_{2}$ emissions and $\mathrm{PM}_{2.5}$ emissions are shown in Fig. 12. It reveals SWHP system can reduce $\mathrm{CO}_{2}$ emissions of $26 \%, 20 \%, 7 \%$ and $4 \%$ respectively compared with status-quo system in Tianjin, Qingdao, Shanghai and Ningbo. Therefore, SWHP system can alleviate $\mathrm{CO}_{2}$ emissions. Similar conclusions can be drawn for $\mathrm{PM}_{2.5}$ emissions.

When comparing SWHP with coal boiler systems in heating, sensitivity analysis is carried out to investigate SWHP SCOP influence on its $\mathrm{CO}_{2}$ emissions mitigation. Tianjin is used as an example and 3 scenarios with different electricity mix are considered: current status scenario, IEA2040 China scenario and Sweden scenario. Current scenario represents currently in Tianjin, zero-carbon electricity accounts for $2 \%$ in grid mix. IEA2040 China scenario refers to north China grid will reach a mix where zero-carbon electricity accounts for $30 \%$ of supply by the year 2040, according to IEA's projection. Sweden scenario represents if north China grid can reach a mix similar to Sweden, whose zero-carbon electricity accounts for $90 \%$ of total supply. Zero-carbon electricity refers to hydro, wind, solar and nuclear power. Scenario results are displayed in Fig. 13.

It can be seen from Fig. 13 that under current situation in Tianjin, SWHP has to reach a minimum SCOP of 2.4 to actually save $\mathrm{CO}_{2}$ emissions compared with using coal boilers. If SWHP SCOP is lower than 2.4, it will lead to negative saving, which means SWHP will result

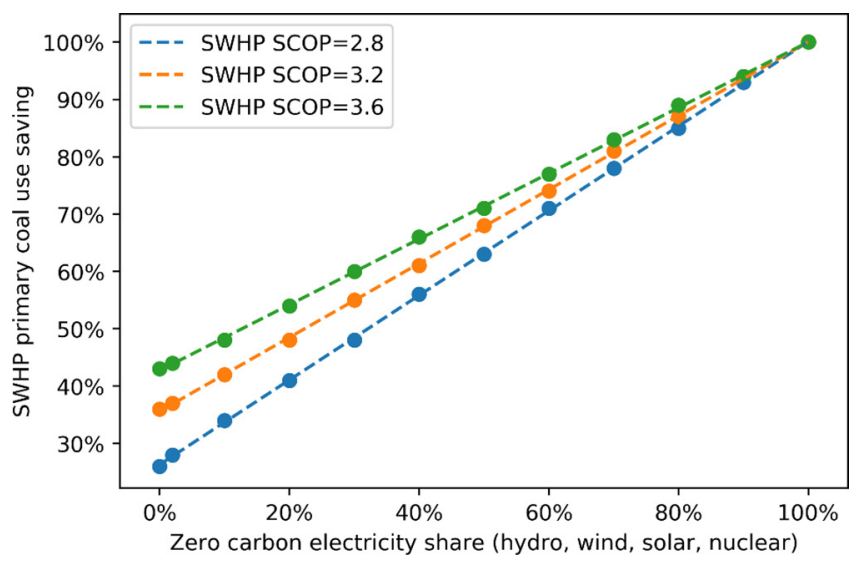

Fig. 10. Zero-carbon electricity influence on SWHP coal PEU saving compared with coal boiler heating. 

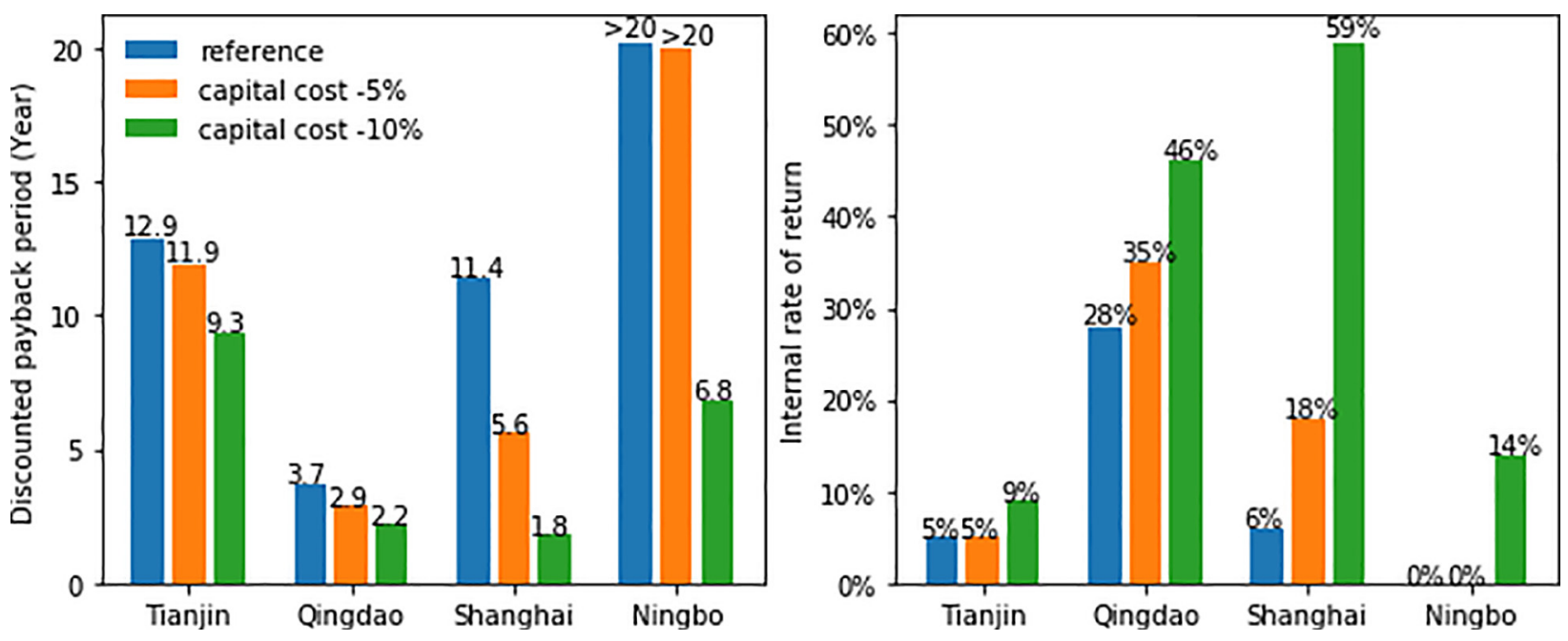

Fig. 11. Discounted payback period and internal rate of return of seawater heat pump relative to status-quo technology.

in more $\mathrm{CO}_{2}$ emissions compared with directly burning coal for space heating. Fig. 13 also shows that when zero-carbon electricity takes more share in local electricity grid mix, using SWHP can always save $\mathrm{CO}_{2}$ emissions compared with coal boilers, so environmentally speaking coal boiler systems should be phased out in the long run.

\subsection{Geographical potential of seawater heat pump}

SWHP geographical potential for the four case study cities are displayed in Fig. 14.

The red heat map shows city building density, which reflects the spatial distribution of buildings and how far away the city core is from seawater. Fig. 14(a) shows $4.8 \%$ buildings in Tianjin is within $5 \mathrm{~km}$ distance to the sea, its total residential floor area is 65.7 million $\mathrm{m}^{2}$. Fig. 14(b) shows Qingdao has the highest SWHP geographical potential for SWHP installation, which is $56.3 \%$ for building numbers $(75,866$ buildings within $5 \mathrm{~km}$ distance to the seawater) and floor area of 382.2 million $\mathrm{m}^{2}$. Qingdao's city core sits closely beside the seawater, which is a great advantage for using seawater for space heating and cooling. SWHP can provide space heating and cooling to $6.8 \%$ buildings in Shanghai that locates within $5 \mathrm{~km}$ to the seawater. Such residential floor areas is 172.8 million $\mathrm{m}^{2}$ (see Fig. 14(c)). Ningbo, however, is located relatively far away from the sea, makes it less feasible to utilize seawater for space heating and cooling from geographical point of view

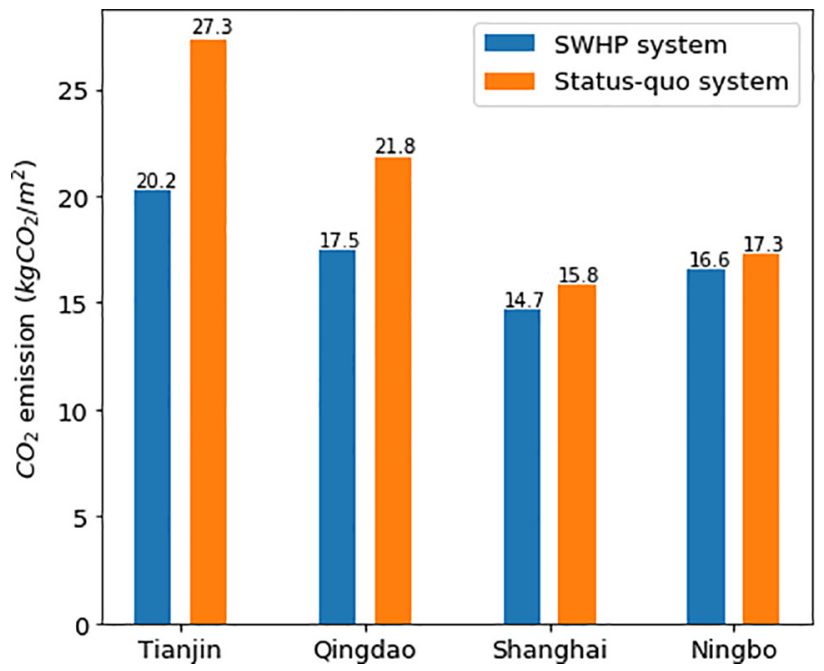

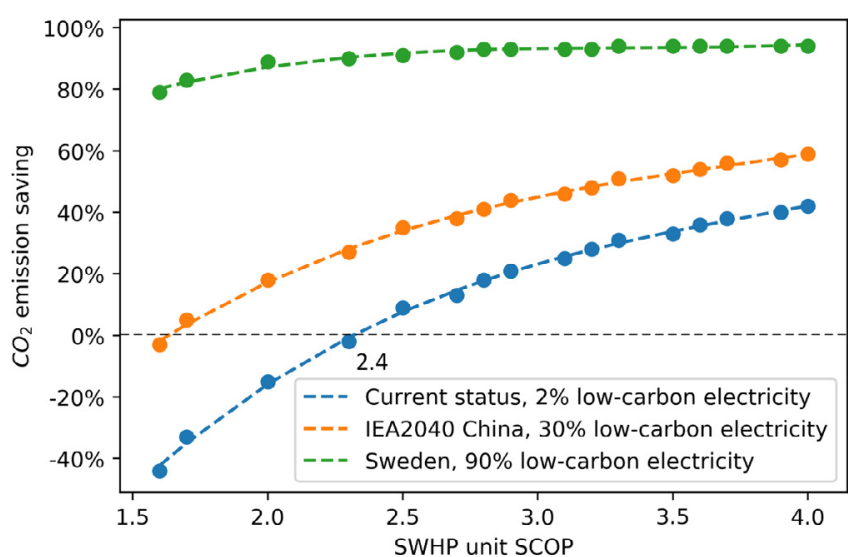

Fig. 13. SWHP SCOP influence on $\mathrm{CO}_{2}$ emissions saving compared with coal boilers, under 3 scenarios.

(see Fig. 14(d)).

\subsection{Influence from energy system transition, social aspects and long-term} climate change on seawater heat pump potential

Traditional district heating systems are based on fossil energy CHP

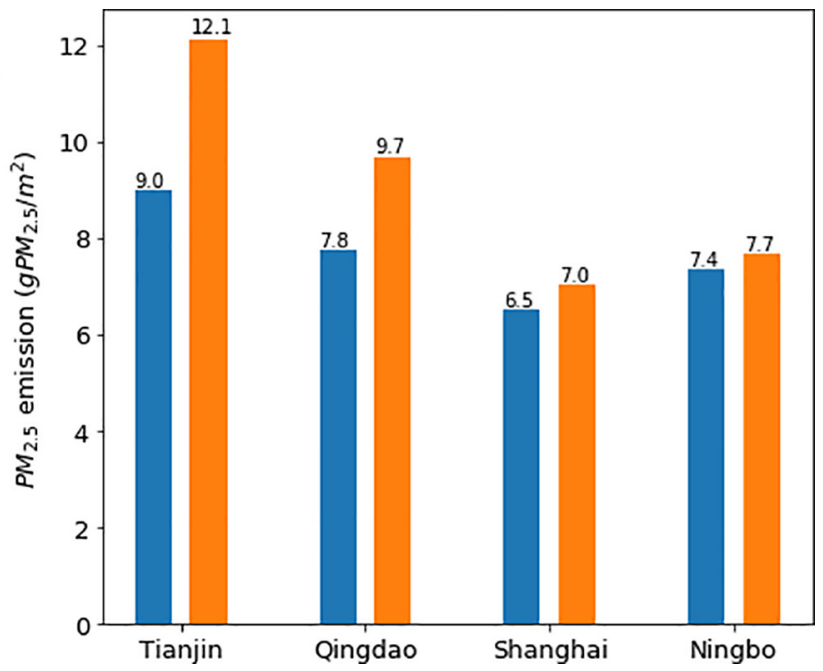

Fig. 12. $\mathrm{CO}_{2}$ emissions and $\mathrm{PM}_{2.5}$ emissions of using seawater heat pump and status-quo technology. 

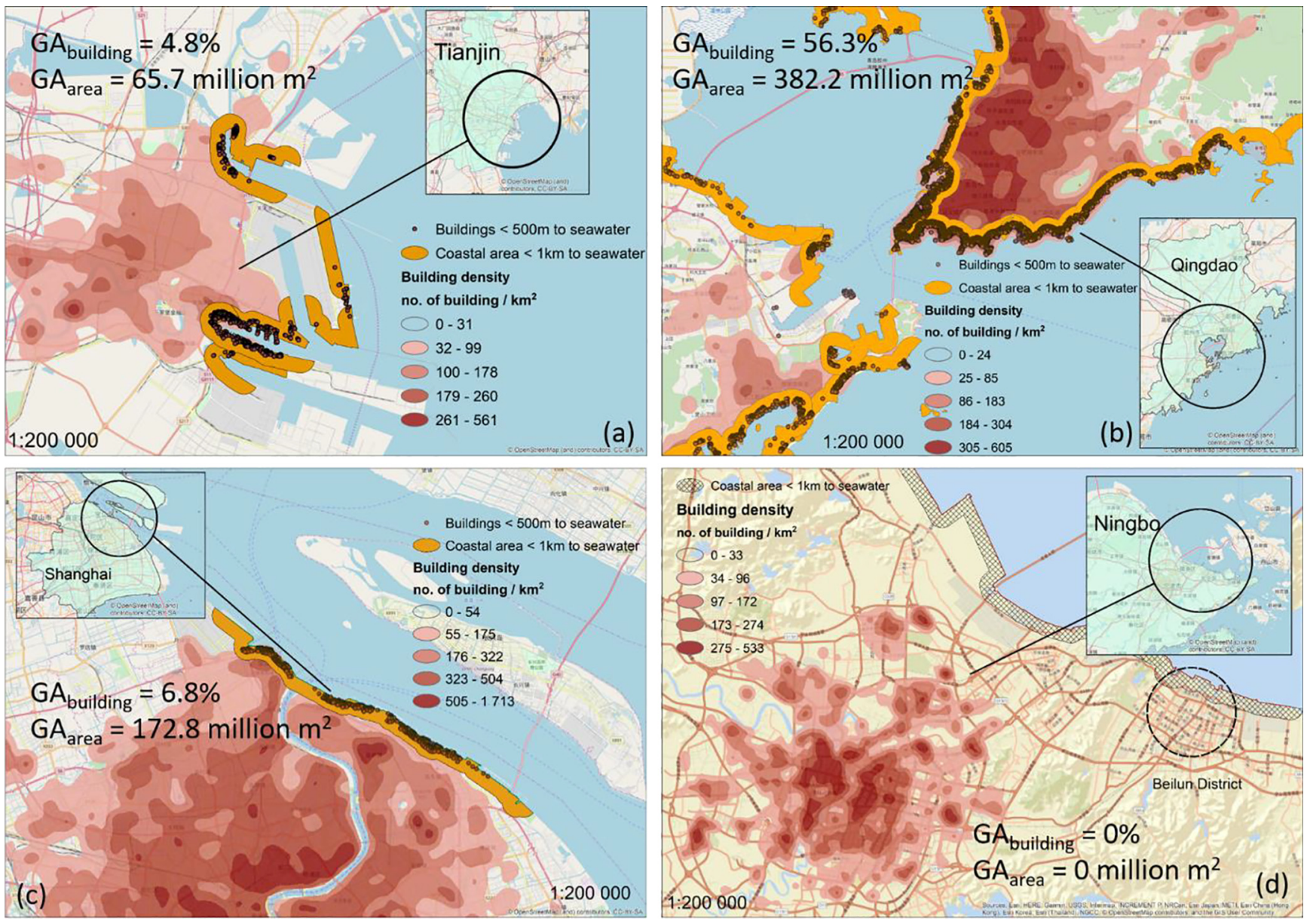

Fig. 14. Geographical potential of seawater heat pumps in case study cities.

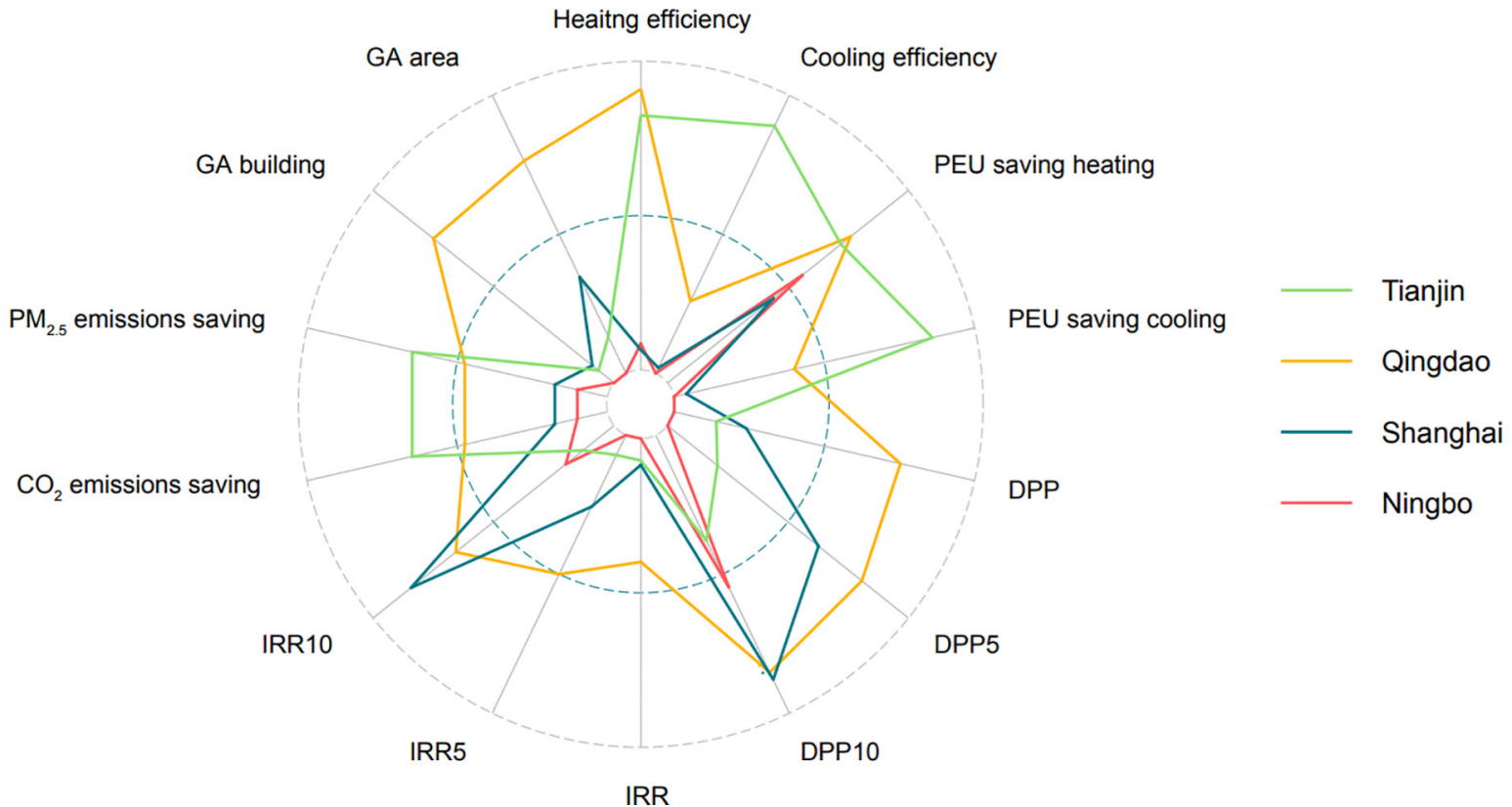

Fig. 15. Relative potential of seawater heat pump in case study cities.

or fossil energy regional boiler, which supply high temperature space heating water (around $100{ }^{\circ} \mathrm{C}$ or higher) to heat users. Lund et al. defined the current district heating systems as the 2nd generation district heating system [69]. For future decarbonized heating system, renewable heat sources and recoverable excess heat by using heat pumps will play a pivotal role, so that lower supply temperature and more diverse 4th generation district heating system can be formed [70], to entirely substitute traditional fossil heating. For example, SWHP can 


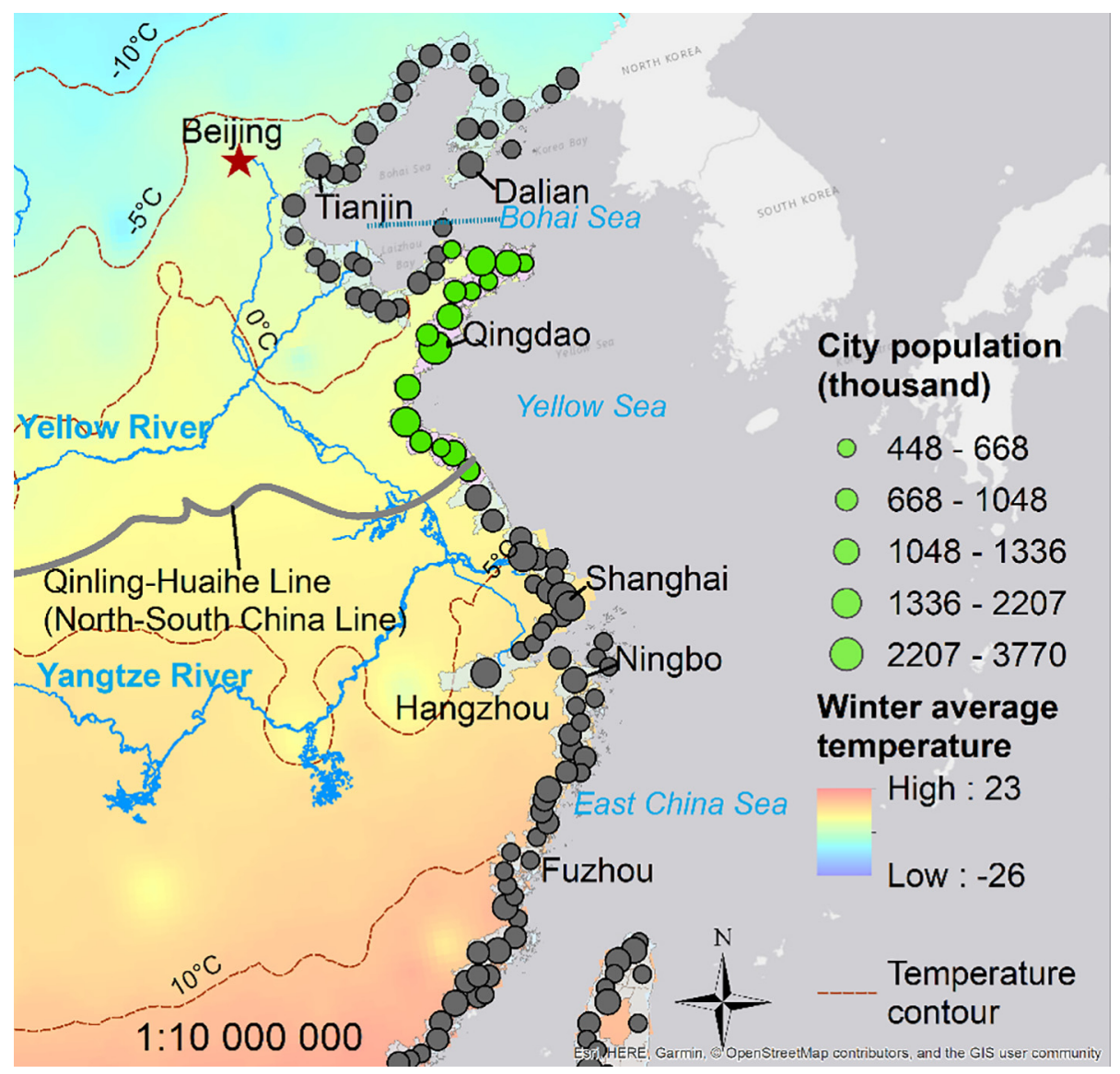

Fig. 16. Coastal cities with seawater heat pump implementation potential (green circles).

serve as a candidate sustainable energy technology in such energy system transition to supply low temperature district heating. Recovering waste heat from gas boilers by using absorption heating technologies is also receiving attentions [71]. On the other hand, distributed heating technologies, characterized by heat pumps, are essential components for future low-carbon energy systems. Local heat consumers thus have the potential to become a heat producer and sell the heat to the thermal grid, which makes them prosumers. Nevertheless, the transition caused by changes in retrofitting the thermal infrastructure yields higher costs [72], and the economic competitiveness is the heart for future energy system transition in the heat industry. This is also the challenge SWHP technology is facing.

For SWHP applications from social aspects, in north China, commercial building owners and public building owners such as hotels and hospitals, have more motivation to use SWHP instead of fossil energy district heating for space heating. This is due to large scale SWHP operating cost is cheaper and consequent payback period can be as short as 4 years. Also, SWHP system has much lower atmospheric pollutants emissions compared with fossil energy district heating. For residential building owners, the interest to install SWHP systems is low since the SWHP application scale is small and economic profitability is limited. In south China, when comparing SWHP with ASHP, SWHP has to reach a satisfactory efficiency value so that commercial and public building owners would consider installing a SWHP.

As climate change and global warming worsening, the rise of seawater temperature will change the coastal marine systems [73]. The rise of seawater temperature, on one hand, will favor SWHP operation in winter for space heating, but will reduce SWHP efficiency for space cooling in summer. The associated changes of sea chemistry can influence seawater salinity and sea organisms [74], which will enhance corrosion and biofouling on SWHP applications. For long term consideration, spatial analysis should investigate the influence of climate change, especially seawater temperature rise and sea chemistry change at different coastal cities of China, to quantify SWHP long-term application potential under the background of climate change.

\section{Conclusions}

From results of case study, it can be concluded that:

- From technical point of view, SWHP system is more feasible in north cities such as Tianjin and Qingdao. When compared with coal boiler heating system, SWHP heating can save up to $19 \%$ fossil fuel primary energy use. When compared with split type air-conditioners, SWHP space cooling can save up to $43 \%$ primary energy use. In cooling mode, seawater temperature in north China favors SWHP efficiency, since during space cooling seasons, seawater temperature is much lower than ambient air temperature, which decreases SWHP condensation temperature compared with air-conditioners. Thus a higher cooling SCOP can be achieved. Increasing zero-carbon electricity share in grid mix as well as improving SWHP SCOP can increase SWHP's fossil fuel primary energy use saving.

- From economic point of view, under current status SWHP is more feasible in Qingdao than in Tianjin, Shanghai and Ningbo when compared with local status-quo system, as the DPP in Qingdao can be as short as 3.7 year and corresponding IRR is $28 \%$. The DPPs and IRRs in Shanghai and Ningbo are more sensitive to SWHP system capital cost reduction than in Tianjin and Qingdao. When SWHP capital cost is reduced by $5-10 \%$, the DPP can be greatly shortened from 11 year to 2 year in Shanghai. Therefore, in the future when SWHP technology further develops and its cost reduces, SWHP will have more economic potential in Shanghai and Ningbo compared 
with Tianjin

- From environmental point of view, SWHP has potential in all case study cities. Replacing fossil fuel heating systems in Tianjin and Qingdao into SWHP systems can save up to $26 \% \mathrm{CO}_{2}$ emissions and $\mathrm{PM}_{2.5}$ emissions, which will contribute greatly to improve local air quality. SWHP applications in Shanghai and Ningbo can also save up to $7 \%$ of both air pollutants emissions. Such saving can be further increased by increasing zero-carbon electricity share in the electricity grid as well improving SWHP SCOP. It has to be pointed out that for north Chinese cities such as Tianjin, when SWHP system is compared with coal boiler system, SWHP unit has to reach a minimum SCOP of 2.4 to guarantee it can actually save $\mathrm{CO}_{2}$ emissions than direct burning coal for space heating. In the future as zero-carbon electricity takes more share, coal boiler should be gradually phased out.

- From geographical point of view, Qingdao has the highest potential to install SWHP systems. Tianjin and Shanghai has relatively good potential to use seawater for space heating and cooling. Ningbo will have more potential when the city expands towards the coastlines in the future.

One way of displaying all KPIs for case study cities is by using Fig. 15, a radar map. Values are normalized to a range from zero to one so that relative advantages can be displayed. Zero means no potential and one means full potential. Theoretical maximum value of each index is set to be one and theoretical minimum value is set to be zero. DPP, DPP5 and DPP10 refers to SWHP capital cost as reference case, capital cost reduced by $5 \%$ and capital cost reduced by $10 \%$ respectively. Same explanation is used for IRR, IRR5 and IRR10.

From Fig. 15, Qingdao shows relative advantages of implementing SWHP reflected by most KPIs. Similar cities geographically close Qingdao could thus be recommended for SWHP installations, which are identified in Fig. 16 as green circles. These cities are located by Yellow Sea, and to the north of Qingling-Huaihe Line (North-South China Line).

\section{Declaration of Competing Interest}

The authors declare that they have no known competing financial interests or personal relationships that could have appeared to influence the work reported in this paper.

\section{Acknowledgements}

The authors acknowledge China Scholarship Council, China (CSC file 201407930004). This research is supported by the Joint China Sweden Mobility: National Natural Science Foundation of China (NSFC China, funding no. 51811530019) and Swedish Foundation for International Cooperation in Research and Higher Education (STINT Sweden, funding no. CH2017-7318).

Special thanks to Dr. WANG Sheng from Gree Electrics in supporting heat pump engineering data.

Special thanks to Dr. ZHONG Wen in helping on figure visualization.

Special thanks to Dr. Nelson Sommerfeldt in helping with EnergyPlus.

\section{Appendix A. Supplementary data}

Supplementary data to this article can be found online at https:// doi.org/10.1016/j.enconman.2019.112240.

\section{References}

[1] International Energy Agency, "World Energy Outlook 2017; 2018

[2] Duan H, Zhang G, Wang S, Fan Y. Robust climate change research : a review on multi-model analysis Robust climate change research : a review on multi-model analysis. Environ Res Lett 2019.

[3] David A, Mathiesen BV, Averfalk H, Werner S, Lund H. Heat Roadmap Europe: Large-scale electric heat pumps in district heating systems. Energies 2017;10(4):1-18.

[4] Su C, Madani H, Palm B. Heating solutions for residential buildings in China: Current status and future outlook. Energy Convers Manage 2018;177:493-510.

[5] Friotherm, Vartan ropsten - the largest sea water heat pump facility worldwide, with 6 unitop 50fy and 180MW total capacity; 2005.

[6] Friotherm, "Oslo - Fornebu: Sustainable development with a district heating/ cooling system using a Unitop ${ }^{\circledR} 28 / 22$ CY." [Online]. Available: https://www. friotherm.de/wp-content/uploads/sites/2/2017/11/oslo_fornebu_e004_uk.pdf.

[7] Song Y, Akashi Y, Yee J-J. Effects of utilizing seawater as a cooling source system in a commercial complex. Energy Build Oct. 2007;39(10):1080-7.

[8] Shu H, Duanmu L, Zhang C, Zhu Y. Study on the decision-making of district cooling and heating systems by means of value engineering. Renew Energy Sep. 2010;35(9):1929-39.

[9] Shandong Provincial Center for Quality Supervision and Test of Building Engineering, "Weihai Jing Ya Hotel Seawater Heat Pump System; 2011.

[10] EHPA, "Large Heat Pumps in Europe: Sea water heat pump for district heating in Norway," 2018. [Online]. Available: http://ehpa.peak-sourcing.com/about/news/ article/large-heat-pumps-in-europe-sea-water-heat-pump-for-district-heating-innorway/. [Accessed: 01-May-2019].

[11] Nowacki J. Large Water Source Heat Pumps - The Swedish Experience; 2014.

[12] PlanEnergi, Oversigt over store el-drevne varmepumper, som producerer varme til danske fjernvarmenet; 2017.

[13] Friotherm, 5 Unitop ${ }^{\circledR} 50 \mathrm{FY}$ heat pump/chiller units simultaneously generate $90 \mathrm{MW}$ heat energy and $60 \mathrm{MW}$ chilled water; 1990.

[14] UCL. Seawater heating system, Duindorp/scheveningen," 2019. [Online]. Available: https://www.ucl.ac.uk/clues/files/hague. [Accessed: 01-May-2019].

[15] Martin M. Water Source Heat Pump (WSHP) report; 2015.

[16] Alaska SeaLife Center, "Sea Water Heat Pump Project," 2013. [Online]. Available: http://www.juneau.org/sustain/energy/local-energy-sources/heat-pumps/ documents/JCOSSeawaterHeatPumppresentationForumApril112013.pdf. [Accessed: 01-May-2019].

[17] Headquarters Magazine. Coal Harbour \& the Vancouver Convention Centre. Vancouver; 2011.

[18] Zhen L, Lin DMM, Shu HWW, Jiang S, Zhu YXX. District cooling and heating with seawater as heat source and sink in Dalian, China. Renew. Energy Dec. 2007;32(15):2603-16.

[19] Friotherm. Dalian-Xinghai: Environment-friendly heating and cooling for a business district in China, with 3 Unitop ${ }^{\oplus} 33 / 28$ units; 2007.

[20] Termoekonomi, "Xinghai Bay Area, Dalian.".

[21] Su C. Personnal communication; 2019.

[22] Sun X, Ferris T. The Kigali amendment's and china's critical roles in evolving the montreal protocol. Nat Resour Environ 2018;33(2).

[23] Lundqvist P. System thinking for evaluation of the performance of heat pump systems. 23rd International Congress of Refrigeration. 2011. p. 3264-71.

[24] Madani H, Claesson J, Lundqvist P. Capacity control in ground source heat pump systems: Part I: Modeling and simulation. Int J Refrig 2011;34(6):1338-47.

[25] Talyor P. Quantitative methods in geography: an introduction to spatial analysis; 1977.

[26] Lund R, Persson U. Mapping of potential heat sources for heat pumps for district heating in Denmark. Energy Sep. 2016;110:129-38.

[27] Baseer MA, Rehman S, Meyer JP, Alam MM. GIS-based site suitability analysis for wind farm development in Saudi Arabia. Energy Dec. 2017;141:1166-76.

[28] Siyal SH, Mörtberg U, Mentis D, Welsch M, Babelon I, Howells M. Wind energy assessment considering geographic and environmental restrictions in Sweden: A GIS-based approach. Energy Apr. 2015;83:447-61.

[29] Hong T, Koo C, Park J, Park HS. A GIS (geographic information system)-based optimization model for estimating the electricity generation of the rooftop PV (photovoltaic) system. Energy Feb. 2014;65:190-9.

[30] Fitzgerald N, Lacal Arántegui R, McKeogh E, Leahy P. A GIS-based model to calculate the potential for transforming conventional hydropower schemes and nonhydro reservoirs to pumped hydropower schemes. Energy 2012;41(1):483-90.

[31] Li J, Zhang Y. GIS-supported certainty factor (CF) models for assessment of geothermal potential: A case study of Tengchong County, southwest China. Energy Dec. 2017;140:552-65.

[32] Su C, Madani H, Palm B. Building Heating solutions in China: A spatial technoeconomic and environmental analysis. Energy Convers Manage Jan. 2018;179:201-18.

[33] Universitat Politècnica de València, "IMST-ART, A SIMULATION TOOL to assist the selection, design and optimisation of refrigeration equipment and components.".

[34] Zheng W, Ye T, You S, Zhang H. The thermal performance of seawater-source heat pump systems in areas of severe cold during winter. Energy Convers Manage Jan. 2015;90:166-74.

[35] Zheng XS, You J, Yang G. Chen "Seepage and heat transfer modeling on beach well infiltration intake system in seawater source heat pump. Energy Build 2014;68(Part A):147-55.

[36] Jia X, Duanmu L, Shu H. Effect of seawater intake methods on the performance of seawater source heat pump systems in cold climate areas. Energy Build 2017;153:317-24.

[37] Cristiani P, Giancola U. Prevention of fouling and microbial corrosion in power stations using seawater as a coolant. Heat Exchanger Fouling Mitigation and Cleaning Technologies Publico, Publ., Essen, D. 2000. p. 334.

[38] Siegenthaler J. Modern hydronic heating: for residential and light com- mercial buildings. Nelson Education; 2012. 
[39] Porak DN, Van Zwieten JH, Rauchenstein LT. Florida's Sea water cooling resource: an updated assessment," Ocean. 2012 MTS/IEEE Harnessing Power Ocean. 2012.

[40] Honolulu Seawater Air Conditioning LLC, "Honolulu Seawater Air Conditioning," 2014. [Online]. Available: http://honoluluswac.com/index.html. [Accessed: 01May-2019].

[41] Minnett P, Kaiser-Weiss A. Near-surface oceanic temperature gradients; 2012.

[42] Carton JA, Hackert EC. SODA v3.3.1," 2017. [Online]. Available: http://apdrc. soest.hawaii.edu/datadoc/soda_3.3.1.php. [Accessed: 01-May-2019].

[43] Carton J, Chepurin G, Chen L. An updated reanalysis of ocean climate using the simple ocean data assimilation version3 (soda3); 2016.

[44] McNeill L, Edwards M. The importance of temperature in assessing iron pipe corrosion in water distribution systems. Environ Monit Assess 2002;77:229-42.

[45] Rodgers P, Cevallos JG, Bar-Cohen A. Application of thermally enhanced thermoplastics to seawater-cooled liquid-liquid heat exchangers. 5th Eur. Therm. Conf. Netherlands. 2008. p. 12.

[46] Kirk W, Pikul S. Seawater corrosivity around the world: results from three years of testing. Corros. Nat. waters 1990.

[47] Ignatowicz M. Personal communication; 2019.

[48] APDRC, Asia Pacific Data-Research Center.” [Online]. Available: http://apdrc.soest. hawaii.edu/index.php. [Accessed: 01-Dec-2018].

[49] Ignatowicz M, Melinder $\AA$, Palm B. Measurements of standard seawater calls for minor adjustments of seawater ice slurry properties. 11th IIR Conference on Phase Change Materials and Slurries for Refrigeration and Air Conditioning. 2016. p. $162-70$.

[50] Jia X, Duanmu L, Shu H. Large-area seepage and heat transfer model of beach well infiltration intake system for seawater source heat pump. Energy Build Jan. 2018;158:1593-601.

[51] Cristiani P. Solutions to fouling in power station condensers. Appl Therm Eng 2005;25:2630-40.

[52] Powell C. Corrosion and biofouling resistance of copper-nickel in offshore and other marine applications. UK Corrosion \& Eurocorr. 1994.

[53] U.S. Department of Energy, EnergyPlus Documentation: Getting Started; 2018.

[54] Tianjin Architecture Design Institute. Tianjin energy efficiency design standard for residential buildings. Tianjin: Tianjin Housing and Urban-Rural Construction Commission; 2013.

[55] Shandong Provincial Architectural Design Institute; and Shandong Tongyuan Design Group, Design standard for energy efficiency of residential buildings. Jinan: Shandong Department of Housing and Urban-Rural Construction; 2015.

[56] Shanghai Research Institute of Building Sciences Group, Design standard for energy efficiency of residential buildings. Shanghai Housing and Urban-rural Development Management Committee; 2011.

[57] The Architectural Design \& Research Institute of Zhejiang University Co Ltd; and
Zhejiang Province Institute of Architectural Design and Research, Design standard for energy efficiency of residential buildings. Hanghzou: Zhejiang Business University Publishing House; 2015.

[58] Lu Y. HVAC design handbook. China Architecture \& Building Press; 2008.

[59] Li J, Shui B. A comprehensive analysis of building energy efficiency policies in China: status quo and development perspective. J Clean Prod Mar. 2015;90:326-44.

[60] China Association of Building Energy Efficiency, "China Building Energy Consumption Research Report; 2016.

[61] China Electric Power Press. China Electric Power Yearbook 2017. China Electric Power Press; 2017.

[62] Swedish Standards Institute, Air conditioners, liquid chilling packages and heat pumps, with electrically driven compressors, for space heating and cooling - Testing and rating at part load conditions and calculation of seasonal performance, 3rd ed. Stockholm; 2016.

[63] Shu H, Duanmu L, Shi J, Jia X, Ren Z, Yu H. Field measurement and energy efficiency enhancement potential of a seawater source heat pump district heating system. Energy Build Oct. 2015;105:352-7.

[64] Dai L, Li S, Duanmu L, Li X, Shang Y, Dong M. Experimental performance analysis of a solar assisted ground source heat pump system under different heating operation modes. Appl Therm Eng 2015;75:325-33.

[65] The World Bank. Real interest rate," 2018. [Online]. Available: https://data. worldbank.org/indicator/FR.INR.RINR?locations = CN. [Accessed: 01-Jun-2018]

[66] Garg A, Kazunari K, Pulles T, and IPCC -Intergovernmental Panel on Climate Change. 2006 IPCC Guidelines for National Greenhouse Gas Inventories Chapter 1 Introduction. 2006.

[67] Ministry of Ecology and Environment, Technical guide for the compilation of primary source emission inventory of fine particulate matter in the atmosphere; 2012

[68] Haiwen S, Lin D, Xiangli L, Yingxin Z. Energy-saving judgment of electric-driven seawater source heat pump district heating system over boiler house district heating system. Energy Build Jun. 2010;42(6):889-95.

[69] Lund $\mathrm{H}$, et al. 4th Generation District Heating (4GDH). Integrating smart thermal grids into future sustainable energy systems. Energy 2014;68:1-11.

[70] Lund $\mathrm{H}$, et al. The status of 4th generation district heating : research and results. Energy 2018.

[71] Sun F, Zhao J, Fu L, Sun J, Zhang S. New district heating system based on natural gas-fired boilers with absorption heat exchangers. Energy Nov. 2017;138:405-18.

[72] Averfalk H, Ottermo F, Werner S. Pipe Sizing for Novel Heat Distribution Technology; 2019.

[73] Harley CDG, Hughes AR, Kristin M, Miner BG, Sorte CJB, Carol S. The impacts of climate change in coastal marine systems. Ecol Lett 2006.

[74] Bijma J, Pörtner H, Yesson C, Rogers AD. Climate change and the oceans - What does the future hold? Mar Pollut Bull 2013;74(2):495-505. 